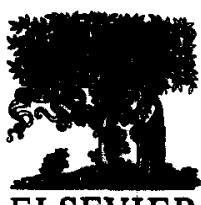

\title{
Kizimen Volcano, Kamchatka - A future Mount St. Helens?
}

\author{
Ivan V. Melekestsev, Vera V. Ponomareva, Oleg N. Volynets \\ Institute of Volcanic Geology and Geochemistry, Petropavlovsk-Kamchatsky, 683006, Russia
}

(Received 2 December 1991; accepted 21 December 1992)

\begin{abstract}
We studied the tectonic setting, morphology, geologic structure, history of eruptive activity and evolution of the composition of the erupted material of Kizimen volcano, Kamchatka, from the moment of its origination 11-12 thousand years ago to the present time. Four cycles, each 2-3.5 thousand years long, were distinguished that characterize the activity of the volcano. All of the largest eruptions were dated, and their parameters determined. We also estimated the volume and the mass of the erupted products, the volcanic intensity of eruption of material during periods of high activity, and the amount of material the volcano ejected at different stages of its formation. It has been shown that the evolution of the composition of the rocks erupted (from dacite to basaltic andesite) takes place as a result of mixing of dacitic and basaltic magma. It is suggested that future eruptions that may take place at Kizimen may be similar to those at Bandai (1888) and Mount St. Helens (1980) volcanoes.
\end{abstract}

\section{Introduction}

Kizimen volcano $\left(55^{\circ} 08.0^{\prime} \mathrm{N}, 160^{\circ} 19.3^{\prime} \mathrm{E}\right.$; altitude $2376 \mathrm{~m}$, according to topographic surveys of 1972 1979 ) is the southernmost of the active volcanoes located in the Central Kamchatka depression (Figs. 1,2). At present, it displays only the fumarolic activity that has been recorded since about 1825 (Vlodavets and Piip, 1957). The only recorded historic eruption occurred in December 1928 and continued to January 1929. The eruption was characterized by "fire flames" in the crater and black smoke from the places where fumaroles are now located. The eruption was accompanied by frequent earthquakes (Piip, 1946).

To date, Kizimen remains one of the least studied active volcanoes in Kamchatka. There are only two papers written as a result of preliminary studies by Boris I. Piip (1946) and a group of scientists (Shantser et al., 1973). In these papers the structure and the history of eruptive activity are examined in a highly generalized way. Complex geologic tephrochronological studies carried out with the help of large-scale air photo interpretation, along with radiocarbon dating, allowed us to considerably expand, and in many ways to make more precise, the existing ideas on genesis, structure, and history of formation of Kizimen volcano. In addition, we have more precisely characterized the evolution of materials, deciphered the features of the recent stage of development of the volcano, and estimated the type and parameters of future eruptions.

The history of the volcano was studied using the method developed by the Tephrochronology Group of the Institute of Volcanology (Braitseva and Melekestsev, 1989; Melekestsev et al., 1989). The reference section of the soil-pyroclastic blanket at the foot of Kizimen (Fig. 3) has been constructed using 23 individual sections from different sectors. For dating the volcanic deposits at Kizimen we used the ash from Sheveluch $\left(\mathrm{SH}_{2},{ }^{14} \mathrm{C}\right.$ age $900 \mathrm{yr} ; \mathrm{SH}_{3}, 1300-1400{ }^{14} \mathrm{C}$ $\mathrm{yr} ; \mathrm{SH}_{5}, 2500-2600{ }^{14} \mathrm{C}$ yr $)$, Ksudach $\left(1700-1800{ }^{14} \mathrm{C}\right.$ $\mathrm{yr})$, Avachinsky $\left(3500{ }^{14} \mathrm{C} \mathrm{yr}\right)$ and Khangar $(6900$ $7000{ }^{14} \mathrm{C}$ yr) volcanoes, that had been identified and 


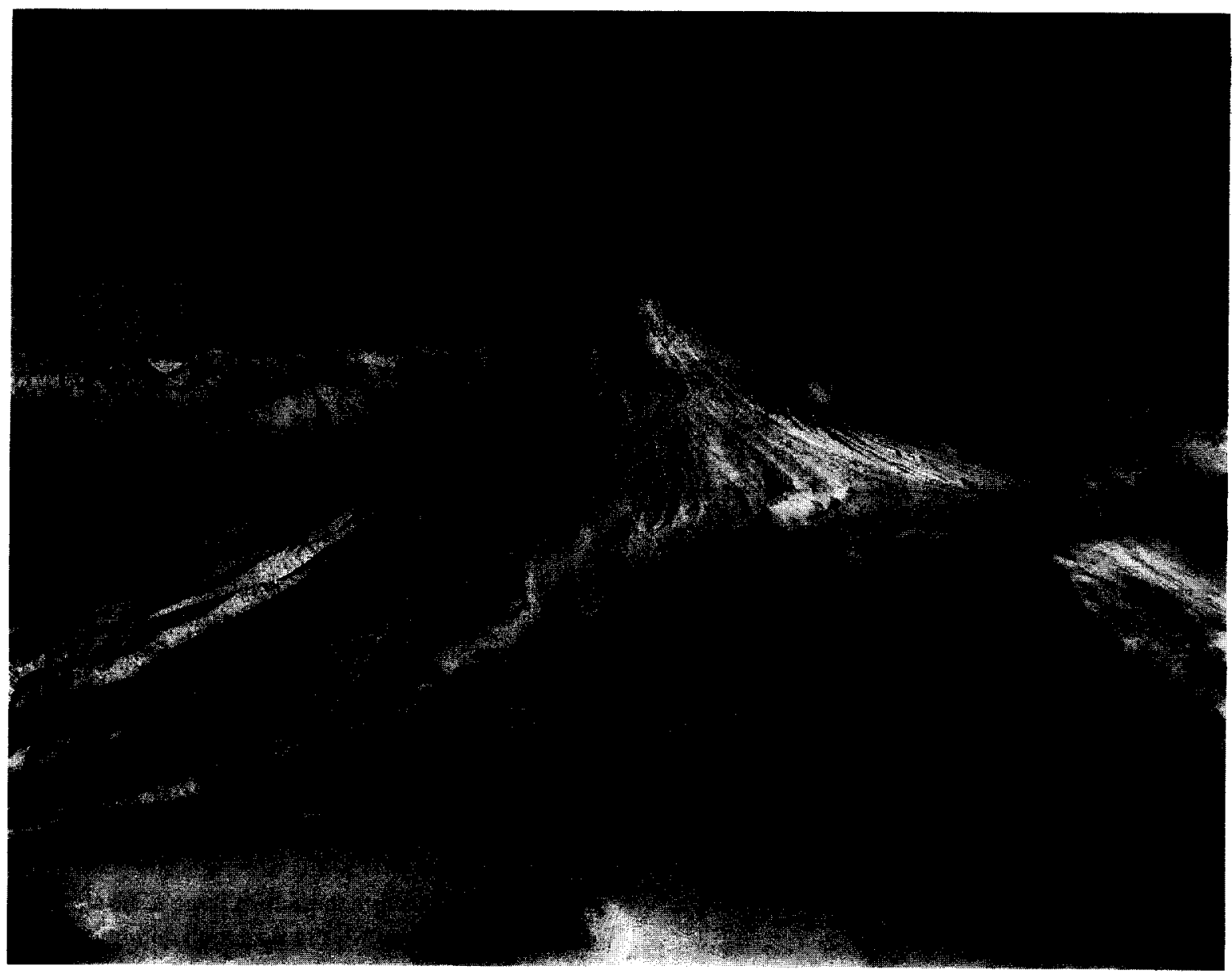

Fig. 1. Kizimen volcano, view from the southwest. Photo by V.N. Dvigalo.

dated earlier (Braitseva et al., in press). The history of activity of Kizimen reported for events in the interval 8-10 thousand years ago was dated with radiocarbon age, while for events in the interval 8 thousand years ago to present we use the calendar age (i.e., radiocarbon age calibrated to sideral years (Stuiver and Kra, 1986) to account for variations in radiocarbon content of the atmosphere).

\section{Tectonic setting, morphology and geologic structure}

Kizimen volcano is located on the SE flank of the Shchapinsky graben and is confined to a system of large amplitude NE-striking faults that includes the junction of the graben with the horst of the Tumrok ridge. The basement of the volcano is composed of volcanogenic

Fig. 2. Geologic-geomorphologic sketch map of Kizimen volcano. $15=$ lava flows $(1,2,3=$ cycle $\mathrm{KZIV}, 4=$ cycle $\mathrm{KZI}, 5=\mathrm{Tamara}$ cinder cone $)$; $6=$ undivided pyroclastic flow deposits and blast deposits of cycle KZVI; $7=$ undivided deposits of the pumiceous pyroclastic and block and ash flows of the KZIV and KZII cycles; $811=$ pyroclastic flow deposits $(8-$ cycle KZIV; $9=$ cycles $\mathrm{KZII}$ and $\mathrm{KZIV} ; 10=$ cycles $\mathrm{KZI}$ and $\mathrm{KZII}$; $1 I=$ cycle $\mathrm{KZI}) ; 1215=$ extrusive domes $(12=$ the second half of cycle $\mathrm{KZIV} ; 13=$ the first half of cycle $\mathrm{KZIV} ; 14=$ cycle $\mathrm{KZII} ; 15=$ cycle $\mathrm{KZI}$ ) $; 16=$ Tamara cinder cone; $17=$ craters; $18=$ faults of various throw; $19=$ mudflow deposits of cycle KZIV; $20=$ collapse deposits and scars; $21=$ accumulative plains ( $a=$ alluvial, $b=$ proluvial, $c=$ lacustrine ); $22=$ glacial landforms of phase II of the Upper Pleistocene glaciation ( $a, b=$ areas of hummock-basin relief, $c=$ moraines); $23=$ erosional windows; $24=$ fragments of lava plateaus; $25=$ the direction of transportation of the fragmented material; $26=$ the boundary of deposits related to Kizimen volcano, excluding distal tephra. 


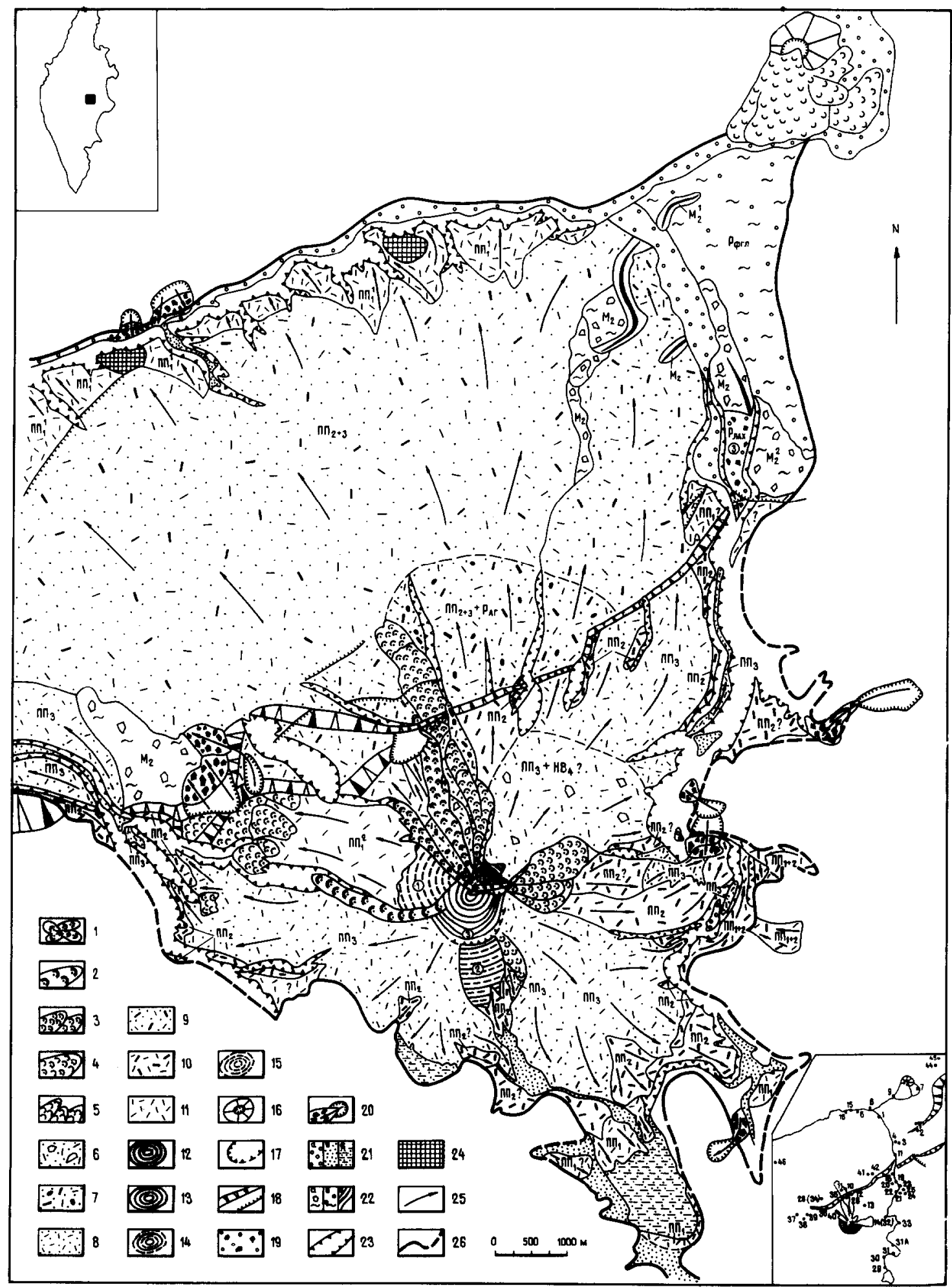


and volcanogenic-sedimentary rocks of the Upper Miocene Shchapinsky suite, and of volcanic rocks of Late Pliocene-Pleistocene age (Shantser et al., 1969).

All scientists recognize the Late Pleistocene-Holocene age of Kizimen to the extent that its deposits fill troughs formed during Late Pleistocene glaciation.

The dimensions of Kizimen are typical of the Kamchatkan volcanoes. The area of its base including the plains at its foot is about $120 \mathrm{~km}^{2}$; the relative elevation of the volcano above the Levaya Shchapina River, 1950 to $2000 \mathrm{~m}$. The overall volume of the volcano, including the rocks of the basal plains, is about $25 \mathrm{~km}^{3}$.

In its morphology, Kizimen is very peculiar and does not have any analogies within the Kurile-Kamchatka region (Figs. 1,2). The upper part of the volcano has a very complex structure, though in its shape it resembles the cones of usual stratovolcanoes. The upper part presents a combination of closely spaced extrusion domes of different size, age and degree of weathering with their thick agglomerate mantles; lava flows that differ in morphology, length, and composition; and lastly, steep $\left(8-10^{\circ}\right)$ plains of blast deposits and pyroclastic flows. The characteristic form at the foot of the volcano is a smooth plain $\left(2-5^{\circ}\right)$ of pyroclastic flows cut by a net of radial valleys. The thickness of the exposed pyroclastic deposits ranges from 40 to $170 \mathrm{~m}$.

The area of the Shchapinsky graben where Kizimen is located is cut by a system of faults (Luchitsky, 1974) that break not only the pre-Kizimen deposits but the volcano itself into numerous blocks. The most distinctly expressed (see Fig. 2) is a complex system of NE-striking faults which deformed the edifice of Kizimen in the northwest. The vertical amplitude of the faults ranges here from $50-60 \mathrm{~m}$ at the NE end of the faulting zone to $170-200 \mathrm{~m}$ at its SW end, where a step-like dome-shaped uplift is located that disappears beneath the volcano.

The volcanic activity within the Tumrok morphostructure terminated in the first half of the Pleistocene about 200-300 thousand years ago (Luchitsky, 1974). However, in the Late Pleistocene the magma chambers of the volcanoes existing here became active again as a result of tectonic rupture processes when the Shchapinsky graben and the Tumrok ridge horst were formed. Peculiar 'electroplating' of these differentiated magma chambers with fresh high-temperature basaltic magma gave rise to the formation of Kizimen volcano and to the earlier formation of the Tamary cinder cone (named by us, see Fig. 2) and a few other small centers of basaltic and andesitic volcanism whose lavas and tuff breccias are exposed in the valley of the stream in the NW sector at the foot of the volcano.

According to T.P. Kirsanova (pers. commun., 1990) these differentiated magma chambers are the heat sources of the Upper Shchapinsky thermal springs located $10 \mathrm{~km}$ NE of Kizimen volcano.

\section{The history of activity}

The first evidence of activity of Kizimen is the series of blast deposits found at points 14 and 28 (see Fig. 2 ). These deposits are covered by tephra and then overlain by dense deposits of the pyroclastic flow $\left(\mathrm{PF}_{1}^{0}\right)$ with columnar jointing. From this, we may infer that the activity of Kizimen started with a large explosion followed by ejection of a great amount of juvenile pyroclastics. We found no tephra produced during the first stages of formation of Kizimen in the studied soilpyroclastic blankets. Taking all this into account, on the basis of the study of the relationship between the

Fig. 3. Reference section of lava and pyroclastic deposits at the foot of Kizimen volcano. Tephra from Kizimen volcano: $l=$ pumiceous lapilli; $2=$ coarse pumiceous ash; 3 = fine light (brownish, yellow) ash; $4=$ fine light (brownish, grey) ash with admixture of coarse pumiceous ash; $5=$ black coarse ash; $6=$ limestone with admixture, lenses and unclear interlayers of light-grey fine ash; $7=$ fine orange ash. Tephra from other volcanoes: $8=$ fine brownish, yellow, light-grey ash; $9=$ black coarse ash; $10=$ fine yellow and light-grey ash with admixture of coarse ash of the same color. $11=$ pyroclastic flows (numbers and hatching correspond to those shown in Fig. 2 ) $; 12=$ extrusive domes; $13=$ large viscous lava flows of KZI cycle; $14=$ other lava flows (hatching corresponds to that in Fig. 2 ); $15=$ limestone; $16=$ moraine; $17=$ humus lenses. Figured points of composition of volcanic rocks (as recalculated water-free): $19=$ lava and pyroclastic flow material; $20=$ tephra. KZI-KZIV =the deposits of the periods of high activity of corresponding cycles of Kizimen formation. The indices of transit ash: $\mathrm{SH}_{2}, \mathrm{SH}_{3}, \mathrm{SH}_{5}=\mathrm{Sheveluch}$ volcano; $K S_{1}=$ Ksudach volcano; $A V=$ Avacha volcano; $G m c h=$ Gamchensky volcanoes, $K H G=$ Khangar volcano; $G T F E=$ Great Tolbachik fissure eruption of 1975-1976. The age of the transit ash after Braitseva et al. (in press). To the right of the column are the dates for the deposits at the foot of Kizimen volcano obtained at the Institute of Volcanology, Far East Div., USSR Academy of Sciences. The thickness of the reference section corresponds to the thickness of the soil-pyroclastic cover at a distance of 8-9 km from Kizimen volcano. 


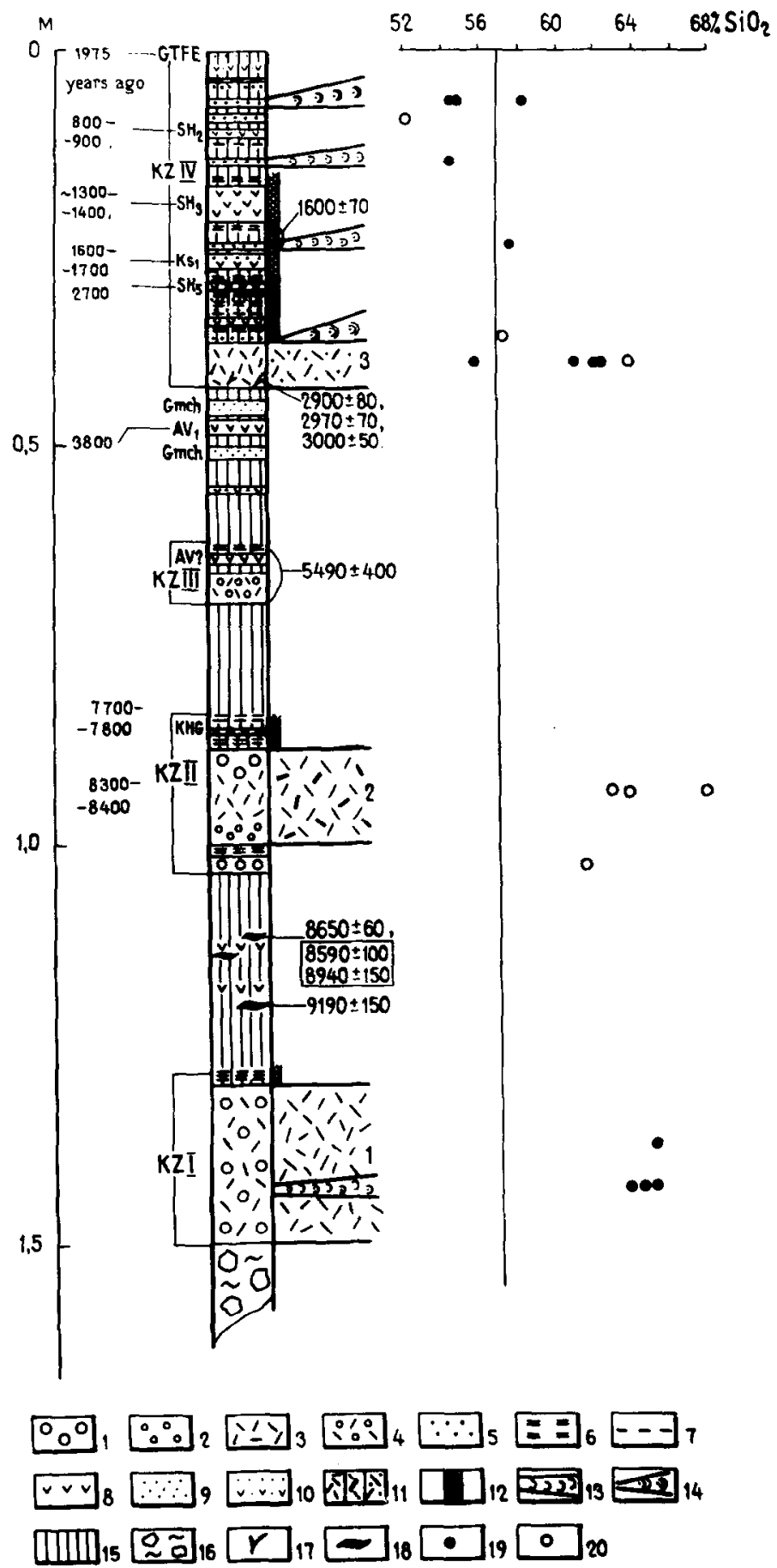




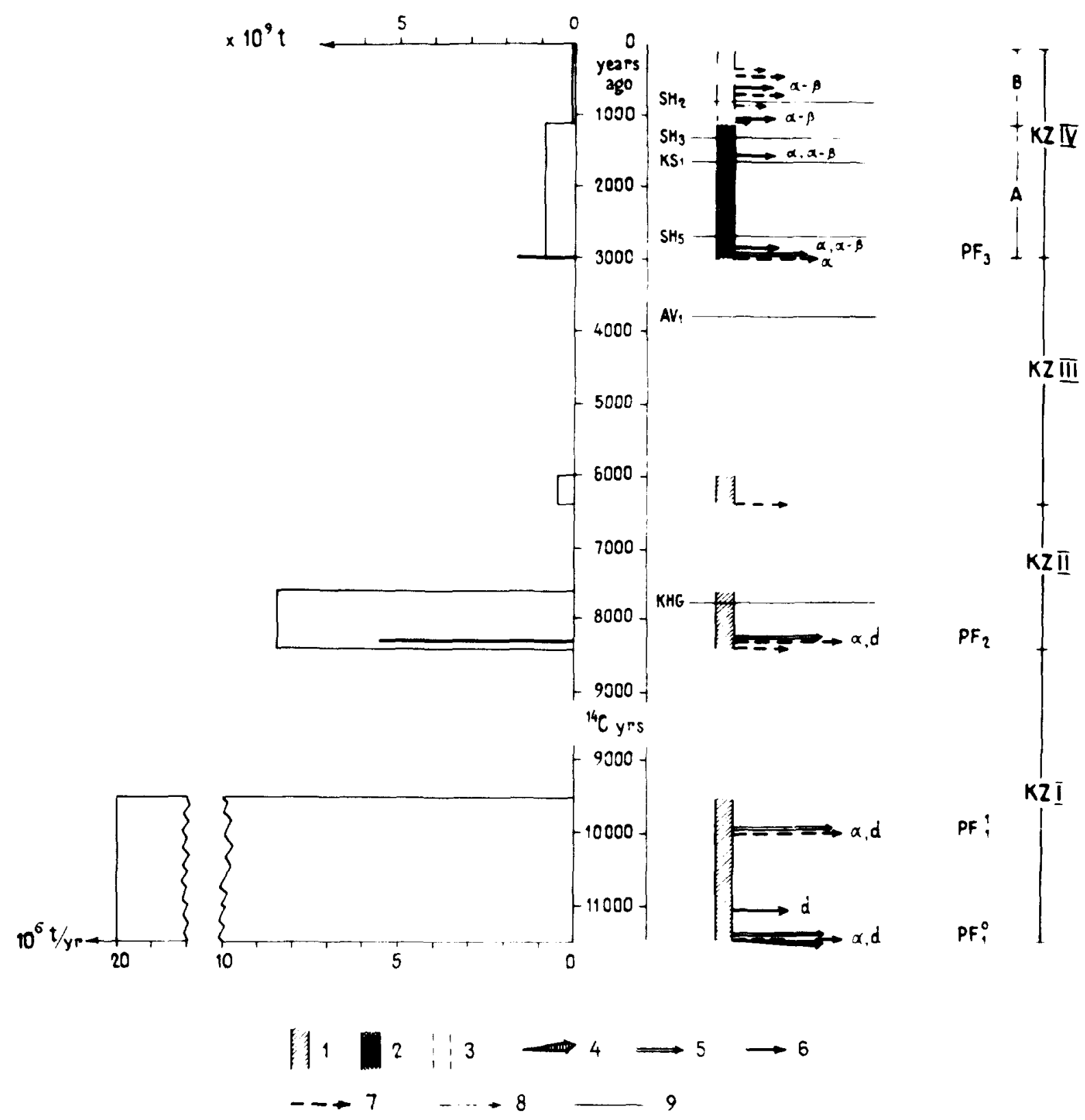

Fig. 4. The dynamics of the eruptive activity of Kizimen volcano. On the right of the time scale, the dynamics of the eruptive activity are shown: $l=$ periods of extrusive-explosive activity: growth of the extrusive dome accompanied by weak-to-moderate ejections of light-grey tephra and formation of small block-and-ash flows; $2=$ as 1 , with rare moderate ejections of black basaltic andesite coarse ash; $3=$ periods of weak explosive activity: small ejections of black basalt-andesitic coarse ash and weak phreatic eruptions; $4=$ directed blast; $5=$ large pyroclastic flows; $6=$ lava flows; $7=$ individual ejections of tephra; $8=$ phreatic eruptions; $9=$ transit ash. KZI-KZIV $=$ cycles of Kizimen activity. $A$ and $B=$ the first and the second phases of KZIV cycle. $P F_{1}-P F_{3}=$ pyroclastic flows. $\alpha-\beta=$ basaltic andesite, $\alpha=$ andesite, $d=$ dacite. The length of the arrows conventionally shows the volumes of material issued during individual eruptions. On the left of the time scale, the volcanic intensity of ejection of juvenile material during periods of increased activity of the cycles KZI-KZIV is shown $\left(\times 10^{6} \mathrm{t} / \mathrm{yr}\right)$ and the location of the largest eruptions and the weight of their juvenile products $\left(\times 10^{9} \mathrm{t}\right)$. 
volcanic deposits of this stage and the depositional and erosional forms of phase II of the Upper Pleistocene glaciation we can infer that Kizimen volcano formed in the Late Pleistocene at the very end of the glacial period, some 11-12 thousand years ago.

Four cycles (KZI-KZIV) are discriminated in the eruptive activity of Kizimen. Each cycle consists of periods of high activity that are followed by waning activity and at the end by relative quiescence. As a rule, every new cycle started with large explosions and terminated with formation of an extrusive dome and outpouring of lava flows. The cycles differed in volume and composition of the erupted rocks, in parameters of the eruptions, in productivity and in the ratio between juvenile and resurgent material (see Figs. 3, 4).

\subsection{Cycle KZI (from 12000-11000 to 8400 years ago}

The cycle started with explosions. Because of the paucity of data on the distribution of the blast and pyroclastic flow deposits and due to complete covering of these deposits by younger ejecta we did not manage to reconstruct them. The explosive stage was then replaced by a predominantly extrusive one. The extrusive dome is not visible anymore because it was destroyed by the ongoing volcanic activity, but its presence is manifested by the remains of the thick coarse mantle at points 14 and 28 that overlie the deposits of the pyroclastic flow. The distinct stratification of the deposits of the mantle points to the multi-stage growth of the dome. The formation of the dome was accompanied by outpouring of very viscous lava flows, 2.5 $3 \mathrm{~km}$ long, of dacitic and andesitic-dacitic composition (see Figs. 2, 3). These flows are confined to the SW sector of the foot of the volcano. Earlier, because of the very great thickness and the fan-shaped structure at the front of the lava flows they were assigned an extrusive origin as opposed to an effusive one (Piip, 1946). Originally, the overall area covered by the lava flows was about $9-10 \mathrm{~km}^{2}$, their volume being $0.8-1.0 \mathrm{~km}^{3}$.

At the moment of termination of the growth of the dome, based very roughly on its reconstruction, the volume of the volcanic edifice was $7-10 \mathrm{~km}^{3}$, and together with distal tephra $\left(0.5-1.0 \mathrm{~km}^{3}\right.$, judging from similar recent eruptions) the collective volume of the juvenile and resurgent material may have reached 7.5$11 \mathrm{~km}^{3}$ and its weight about $20 \times 10^{9}$ tons.
The climactic stage of the cycle took place at the very beginning of Holocene about 10 thousand years ago. A series of catastrophic eruptions was preceded by strong tectonic and volcano-tectonic movements with the formation of a dome-shaped volcano-tectonic uplift. A part of this uplift, broken by large-amplitude $(200-250 \mathrm{~m})$ fractures, into gigantic steps, is now located in the northwest sector of the base of Kizimen (see Fig. 2). The fractures also cut the ends of recently issued lava flows. It is quite possible that during that time the main fault at the northern foot of the volcano was formed.

The subsequent large explosions destroyed a part of this uplift and of the extrusive dome formed earlier: blocks of the dome rocks 5-6 m across were found at the base of the pyroclastic flow $\mathrm{PF}_{1}^{1}$ on the left shore of the Levaya Shchapina River 9-10 km from the eruptive center. The pyroclastic flow $P F_{1}^{1}$, which formed as a result of ejection of andesite-dacitic pyroclastics immediately after the catastrophic eruption, was the largest in the whole history of Kizimen activity with an area of about $80-90 \mathrm{~km}^{2}$ and a volume of $2.4-3.6 \mathrm{~km}^{3}$. The valley of the Levaya Shchapina River was buried by the deposits of this pyroclastic flow over a distance of more than $15 \mathrm{~km}$. In the soil-pyroclastic blanket at a distance of $10-15 \mathrm{~km}$ from the volcano, the light grey indistinctly laminated sands that are synchronous with the $\mathrm{PF}_{1}^{1}$ flow were found together with lapilli and pumice directly on the moraine (points $1,44,45$ ). They resemble pyroclastic surge deposits (Bogoyavlenskaya and Braitseva, 1990). The tephra produced by this catastrophic eruption was not found, but by analogy with recent eruptions of other volcanoes its volume can be estimated at $1 \mathrm{~km}^{3}$.

After eruption of the pyroclastics the formation of the next extrusive dome (dome 1 in Fig. 2) started at the site of the eruptive center. This dome is the oldest of those that are expressed in the morphology of the volcano. Directly at the foot of the volcano there are some deposits of small pyroclastic flows, pyroclastic surges and debris avalanches which compose its thick agglomerate mantle ( $>100 \mathrm{~m}$ ). Based on the reconstruction, the volume of the extrusive massif with its agglomerate mantle was $3.5-4.0 \mathrm{~km}^{3}$, the absolute elevation of the volcano reached $2100-2200 \mathrm{~m}$ and the volume of the Kizimen volcanic edifice $22 \mathrm{~km}^{3}$.

The upper time limit (about 9.5 thousand years ago) of the period of high activity of the cycle KZI at first 
Table 1

Eruptive intensity and productivity of Kizimen Volcano

\begin{tabular}{|c|c|c|c|c|c|c|c|}
\hline \multirow{3}{*}{$\begin{array}{l}\text { Cycle number and its age } \\
\text { span } \\
\left(\times 10^{3} \text { yr ago }\right)\end{array}$} & \multirow{3}{*}{$\begin{array}{l}\text { Duration of high } \\
\text { activity period } \\
\left(\times 10^{3} \mathrm{yr}\right)\end{array}$} & \multicolumn{4}{|c|}{ Quantity of ejecta } & \multirow{3}{*}{$\begin{array}{l}\text { Eruptive intensity of } \\
\text { juvenile material } \\
\text { evacuation } \\
\left(\times 10^{6} \mathrm{t} / \text { year }\right)\end{array}$} & \multirow{3}{*}{$\begin{array}{l}\text { Productivity } \\
\left(\times 10^{6} \mathrm{t} / \text { year }\right)\end{array}$} \\
\hline & & \multicolumn{2}{|c|}{ Volume $\left(\mathrm{km}^{3}\right)$} & \multicolumn{2}{|c|}{ Mass $\left(\times 10^{9} \mathrm{t}\right)$} & & \\
\hline & & $\Sigma$ & Juvenile & $\Sigma$ & Juvenile & & \\
\hline $\mathrm{KZ}$ IV B, 0-1.I & 1.1 & $0.09-0.10$ & 0.03 & $0.17-0.20$ & $0.07 \quad 1.5-$ & 0.06 & - \\
\hline KZ IV A, $1.1-3.0$ & 1.9 & $1.0-1.3$ & $0.7-1.0$ & $1.9-2.5$ & 2.0 & $0.8-1.1$ & $0.3-0.4$ \\
\hline $\mathrm{KZ} \operatorname{IV}(A+B), 0-3.0$ & 3.0 & $1.09-1.40$ & $0.73-1.03$ & $2.07-2.70$ & $1.57-2.07$ & $0.5-0.7$ & 0.3 \\
\hline KZ III, $3.0-6.4$ & 0.4 & 0.1 & 0.1 & 0.2 & 0.2 & 0.5 & 0.1 \\
\hline $\mathrm{KZ}$ II, 6.4-8.4 & 0.6 & $4.4-5.4$ & $3.9-4.7$ & $7.2-8.9$ & $6.2-7.5$ & $7.8-9.4$ & $3.3-3.9$ \\
\hline $\mathrm{KZ} I, 9.5-12$ & $2.0-2.5$ & $23.5-24.0$ & 21 & 50 & 45 & 20 & - \\
\hline LZ I-IV & $6.2-6.7$ & & 26 & & 54 & $8.1-8.7$ & 4.7 \\
\hline
\end{tabular}

Note: $\Sigma=$ total volume and mass of juvenile and resurgent material; $B=$ the second phase of eruptive cycle $K Z I V ; A=$ the first phase of eruptive cycle KZ IV.

approximation was determined by ${ }^{14} \mathrm{C}$ dating (from $8590 \pm 100$ to $9190 \pm 150$ years ago) of the series of buried soils with rare horizons of fine ash that overlie these deposits.

During the first 2.0-2.5 thousand years of its life Kizimen erupted, distal tephra included, about $24 \mathrm{~km}^{3}$ of juvenile and resurgent material with a weight of about $50 \times 10^{9} \mathrm{t}$ (Table 1). The average eruptive intensity was calculated by dividing the mass of the erupted juvenile material by the duration of the period of high activity. Therefore, average eruptive intensity during the cycle KZI was about $22 \times 10^{6} \mathrm{t} /$ year and the main mass of the erupted products was juvenile because the proportion of basement rocks, even at the early stage of the eruptive cycle, did not exceed $10-20 \%$ of the total volume of the pyroclastics, and later this volume decreased further. After the period of high activity, a period of relative repose of about 1100 years long followed.

\subsection{Eruptive cycle KZII (8400-6400 years ago}

The cycle started with a series of moderate eruptions represented in the section of the soil-pyroclastic blanket by 2-3 layers of pumiceous tephra, each $0.001-0.01$ $\mathrm{km}^{3}$ in volume. Then, 8300 years ago a catastrophic eruption occurred, one of the largest in Kamchatka up to that time. Its tephra covered an area of a few hundred thousand $\mathrm{km}^{2}$. This tephra has been found on Bering Island, $360 \mathrm{~km}$ ESE from Kizimen, and near Bolshoy Semiachik volcano, 95 km SSW Kizimen (Braitseva et al., in press). At the foot of Kizimen volcano this tephra is $15-20 \mathrm{~cm}$ thick and is represented by pumiceous bombs and lapilli as well as by coarse and fine ash. The composition of the tephra is andesitic-dacitic and dacitic; its volume is $2.5-3.0 \mathrm{~km}^{3}$. Massive ejection of pyroclastics also resulted in formation of vast (70$80 \mathrm{~km}^{2}$ ) pyroclastic flows $\mathrm{PF}_{2}$. Their thickness ranges from 10 to $60 \mathrm{~m}$. We took the average thickness of these deposits to be $20-30 \mathrm{~m}$ and estimated their volume as $1.5-2.0 \mathrm{~km}^{3}$. The composition of the juvenile material of the pyroclastic flows is andesitic-dacitic.

At the final stage of the period of intensified activity the large extrusive dome 2 formed (see Figs. 2, 4). We suggest that it had been growing for 700 years because thin layers of light grey ash associated with its growth were traced in the sections of the soil pyroclastic cover both under and immediately above the tephra produced by Khangar volcano 7700-7800 years ago. The collective volume of the extrusive dome, its agglomerate mantle and the tephra associated with the eruptions of this cycle is $0.3-0.4 \mathrm{~km}^{3}$. Inasmuch as dome 2 formed somewhat aside from the summit of Kizimen which existed earlier, the absolute elevation of the latter did not increase.

The productivity was determined by dividing the mass of the erupted material by the duration of the period of intensified activity together with the preceding period of relative repose. The productivity calculated for the cycle KZII is approximately $3.6 \times 10^{6} \mathrm{t} /$ $\mathrm{yr}$ ( see Table 1). As the duration of the period of high activity can be estimated as 800 years, the average 
intensity rate was $7.8-9.4 \times 10^{6} \mathrm{t} / \mathrm{yr}$. The cycle terminated with a period of relative repose of about 1200 years long. It is interesting to note that the temporal interval of the period of intensified activity during the cycle KZII and its catastrophic eruption were not accidental: this very period gets into the stage of Early Holocene paroxysmal explosive activity in Kamchatka and the Kuriles (Melekestsev, 1980).

\subsection{Eruptive cycle KZIII (6400-3000 years ago)}

This cycle is notable for the smaller scale of its volcanic activity as compared to the previous two cycles (Fig. 4, Table 1). During increased volcanic activity (6400-6000 years ago) only moderate or small explosive eruptions occurred. The initial explosion was the largest; it ejected about $0.1 \mathrm{~km}^{3}$ of resurgent and juvenile rocks. Coarse blocks produced by the explosion were deposited to the north of the eruptive center. The on-going eruptions are manifested only by thin layers of pumiceous tephra represented by small lapilli and fine ash. Their volume does not exceed $0.005-0.01$ $\mathrm{km}^{3}$. The chemical composition of tephra is dacitic andesite. The productivity was low, less than $0.1 \times 10^{6}$ $\mathrm{t} / \mathrm{yr}$. The eruptive intensity presumably did not exceed $0.5 \times 10^{6} \mathrm{t} / \mathrm{yr}$, i.e. an order of magnitude lower than in the cycle KZII.

\section{Eruptive cycle KZIV (3000 years ago-present}

A large eruption at the beginning of the cycle was crucial in the life of Kizimen. It initiated a new series of eruptions following the long $(\sim 3000 \mathrm{yr})$ repose period that terminated the cycle KZIII. Like the eruptions of the cycles KZI and KZII, this eruption was characterized by a large explosion, ejection of juvenile pyroclastics and formation of pyroclastic flows, and growth of a large extrusive dome with lava flows. However, it also had distinctive features, such as in composition: the juvenile material became generally more basic and contrasting. Along with andesites, basaltic andesites appeared for the first time. The overall volume $\left(0.7-1.0 \mathrm{~km}^{3}\right)$ and the weight $\left(1.5-2.0 \times 10^{6} \mathrm{t}\right)$ of juvenile products were considerably smaller.

As earlier, the major part of the juvenile material formed pyroclastic flows $\left(\mathrm{PF}_{3}\right)$, but their area did not exceed $30-35 \mathrm{~km}^{2}$, which is half the area covered by the pyroclastic flows during the cycles KZI and KZII.
In sections of the soil-pyroclastic blanket close to the volcano, the synchronous $\mathrm{PF}_{3}$ deposits are represented by pyroclastic surge deposits and a small amount of tephra.

In the post-climactic stage of the cycle the activity of the volcano was associated for a very long time (approximately 1100 years ago) with the formation of the $1.0 \times 1.2 \mathrm{~km}$ andesite extrusive dome 3 in the crater (Figs. 2,4 ). The formation of the dome proceeded in many stages and was accompanied by explosive-effusive activity characterized by outpouring of two types of lava flows. The oldest flows (1-2 km long) had a shape of a tear drop and were notable for a large thickness at the front, $>100 \mathrm{~m}$; they were andesitic in composition, the same as the dome. The younger flows were mostly blocky and up to $4 \mathrm{~km}$ long, thinner and more basic in composition. The collective volume of the flows is $0.15-0.16 \mathrm{~km}^{3}$. As a result of numerous explosions and gravitational failures a large agglomerate mantle formed at the base of the dome. By the end of its formation the extrusive dome with its mantle, according to our reconstruction, reached a volume of $0.25-0.30 \mathrm{~km}^{3}$ and became the principal element of the summit of Kizimen volcano. Its absolute elevation may have exceeded the modern height of the volcano.

Judging from the sequence of events, the type of eruptions and the complex of volcanic forms that originated, the activity of Kizimen at that stage resembled that of modern Bezymianny volcano, especially the series of eruptions of the latter that started in 1955 and continue to date. Even extrusive dome 3 at Kizimen very closely resembles the presently forming Novy dome at Bezymianny volcano (Bogoyavlenskaya and Kirsanov, 1981).

The duration of formation of dome 3 was established from the presence of thin horizons of light grey fine tephra in the soil-pyroclastic cover (which may be the traces of the pyroclastic surges); its first layers were found in the section immediately above the deposits of the climactic stage of the cycle KZIV. The last layers are present directly above the marker ash layer $\mathrm{SH}_{3}$ with an age of 1200-1300 years. Therefore, the duration of the initial stage of the cycle KZIV can be estimated as 1900 years, its productivity being 0.3$0.4 \times 10^{6}$ t. Along with light grey (andesitic?) tephra (pyroclastic surge deposits?) we also observed horizons of black coarse ash - at least four times - of 
more basic composition (see Fig. 3), two of which were produced by eruptions that also issued lava.

The volcanic activity of the initial phase of the cycle KZIV was accompanied by sharp intensification of tectonic movements. In particular, large displacement occurred along the fault running across the $\mathrm{N}$ and $\mathrm{NE}$ sectors of the foot of the volcano. The vertical amplitude of the displacement in the area on the Upper Shchapinsky hydrothermal springs and at the point of intersection of the fault with one lava flow of the cycle KZIV presumably amounted to no less than $10 \mathrm{~m}$. Thrust-type faults originated on both flanks of the valley of Poperechny Creek in its middle course (see Fig. 2).

Among the other phenomena directly related to the climactic eruption at the very beginning of the cycle, we should mention a large mudflow that obviously reached the valley of the Left Shchapina River and covered the place where recent Upper Shchapinsky thermal springs are located.

The second phase of the cycle KZIV (1100 years ago-Present) was even more distinctive in its characteristics. First, the explosion that occurred at the beginning of the phase was not followed (like during the first phase of the cycle) by voluminous ejection of juvenile pyroclastics. The explosion destroyed the near-summit sector of extrusive dome 3 and formed a $1.0 \times 0.7 \mathrm{~km}$ crater open to the northeast. The blast deposits with the volume of $0.05-0.06 \mathrm{~km}^{3}$ covered the NE sector of the foot of the volcano to a distance of $3.0-3.5 \mathrm{~km}$ from the eruptive center. After the explosion, part of the crater was filled by the relatively small effusive dome 4 . Its volume, including the agglomerate mantle, is $0.015 \mathrm{~km}^{3}$. Second, the composition of the lavas that issued during formation of the dome, and that of the juvenile tephra, was generally highly basic (as basic as never before in the history of Kizimen). At the same time the lava flows were of relatively low viscosity and small in volume, about $0.012 \mathrm{~km}^{3}$.

In the soil-pyroclastic blanket we found traces of only six eruptions, indicated by ash layers $0.5-3.0 \mathrm{~cm}$ thick at a distance of $3 \mathrm{~km}$ from the volcano. These layers are represented both by juvenile and resurgent material. The real number of the eruptions during the last 1100 years was probably greater, because it is possible that many of these events were similar to the small explosive eruption of 1928-1929, which did not form any visible tephra layer in the soil-pyroclastic blanket.
It is also interesting that intensification of activity of Kizimen shows distinct temporal correlation with local earthquakes. For example, the 1928-1929 eruption was accompanied by frequent earthquakes (Piip, 1946). An episodic increase of fumarolic activity in $1963 \mathrm{fol}-$ lowed relatively large shallow earthquakes of magnitude 6.2 and 5.8 whose epicenters were $25 \mathrm{~km}$ northwest of Kizimen (Fedotov et al., 1966).

During the second half of the cycle KZIV only $0.09-$ $0.10 \mathrm{~km}^{3}$ of material was erupted (Table 1 ). The productivity was calculated as $0.05 \times 10^{6} \mathrm{t} / \mathrm{yr}$, which is an order of magnitude less than in the first half of the cycle.

This low productivity, equivalent to a thermal power of 2.5-3.0 thousand $\mathrm{kW}$ at $400 \mathrm{cal} / \mathrm{g}$ of basalt, is in sharp contrast with the measured thermal power of recent fumaroles $(46,565 \mathrm{kcal} / \mathrm{s}, 200$ thousand $\mathrm{kW})$ (Kirsanova et al., 1983) which grew even higher during the periods of intensification of fumarolic activity. The vents of the recent and older fumaroles are located at the base of extrusive dome 3 , along its perimeter. Here a lot of altered rock was found (Petrov, 1970) which testifies to the presence of a long-lived thermal source that feeds the fumaroles. The high output of the fumaroles and their sustained activity is provided, in our opinion, by intrusion into the Kizimen edifice or directly beneath its base of large volumes of basic magma, of the order of $0.5-1.0 \mathrm{~km}^{3}$. Only a small portion of this magma was erupted onto the surface, while the rest of it stayed at depth in the form of slowly cooling intrusive bodics. The intrusion started, possibly, back in the period of preparation for the climactic eruption of the cycle KZIV which is indicated by the presence of fragments of juvenile basaltic andesites in the pyroclastic flow deposits. Annual heat output produced by recent fumaroles equals the loss of heat during cooling of $3-4 \times 10^{6}$ tons of basaltic magma. For the period 1825-1990 the weight of this cooling magma could have constituted $500-700 \times 10^{6} \mathrm{t}$ and its volume, $0.2 \mathrm{~km}^{3}$ (at $2.8 \mathrm{~g} / \mathrm{cm}^{3}$ ). An other source of heat seems less probable.

The cycles of activity of Kizimen volcano, in terms of their role in the formation of the edifice, type of eruptions and chemical composition of rocks, can be united into a higher level subdivision, a group of cycles or an eruptive stage. The regular decrease in productivity and eruptive intensity from cycle to cycle, the invariant composition of juvenile material, the unusually long duration of the repose period that terminated the 
cycle KZIII and the insignificant parameters of eruptions during the cycle KZIII, allow us to infer that it terminated the first stage of formation of the Kizimen volcano. The edifice that developed during these first three cycles was named Stary (Old) Kizimen volcano; the duration of its life is $5-6$ thousand years.

A new eruptive stage began with the cycle KZIV about 3000 years ago. This marked the beginning of the new volcano. As has been shown above, it differed from the Stary Kizimen volcano in the majority of its parameters: the regime of activity, composition of the juvenile material, productivity, etc. Thus, we propose to name it Molodoy (Young) Kizimen volcano.

Of interest is the similar duration of the cycles distinguished for eruptive activity of Kizimen: KZI 3000 to 3600 years, KZII-2000 years, KZIII-3200 to 3400 years and KZIV-3000 years. The duration of the last cycle (KZIV) approaches the probable limit.

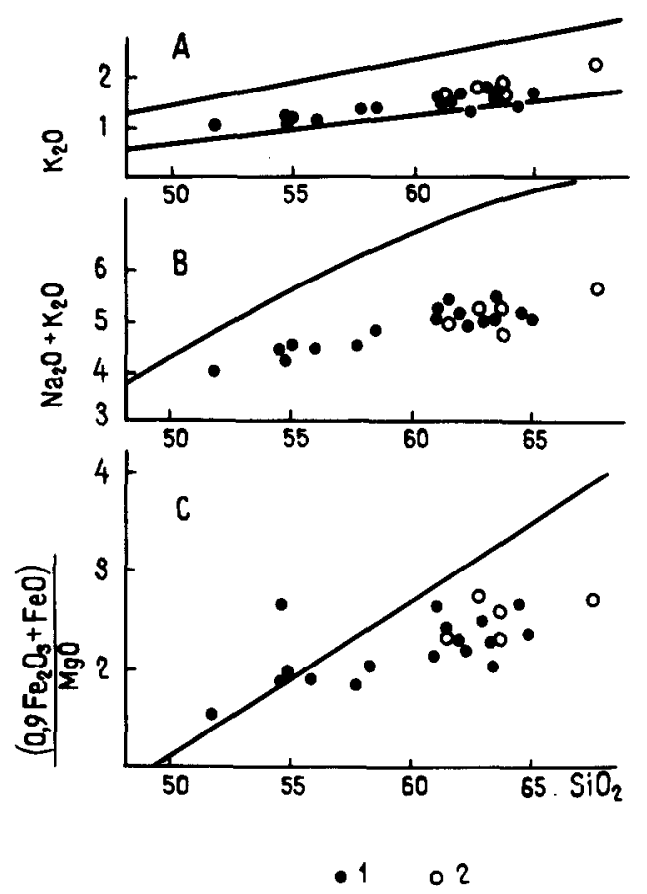

Fig. 5. Classification diagram for the rocks of Kizimen volcano. (A) Field of moderately-potassic rocks after Gill (1981). (B) Lower boundary of the field of subalkaline rocks after Bogatikov (1981). (C) Boundary between calc-alkaline and tholeiitic rocks after Gill (1981). $l=$ lavas and juvenile material of pyroclastic flows; 2 = tephra. Apart from our own data, we also used the data by Shantser et al. (1973).

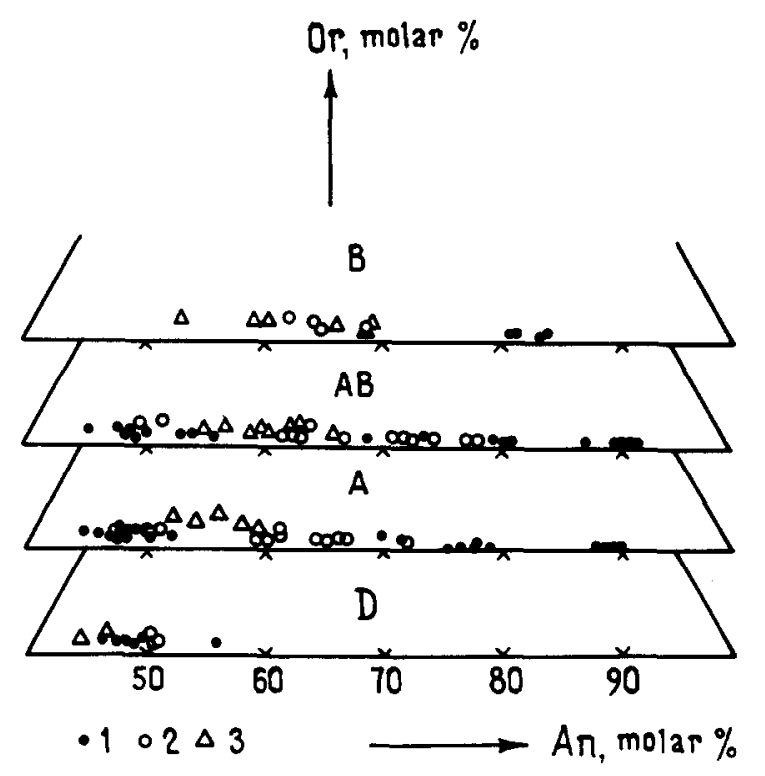

Fig. 6. Composition of plagioclase in the rocks from Kizimen volcano. $12=$ phenocrysts $(1=$ cores, $2=$ rims $) ; 3=$ microlites. $B=$ basalt, $A B=$ basaltic andesite, $A=$ andesite, $D=$ dacite.

\section{Composition, genesis and evolution of the erupted material}

The studies conducted have established that Kizimen is composed of rocks corresponding to the sequence basaltic andesite-andesite-dacite. From early to more recent stages of development we identify a regular increase of basic rocks (Fig. 3). All varieties of the volcanic products belong to the moderately potassic series, and whereas the dacites and andesites get into the field of calc-alkaline series, the more basic varieties lie on the boundary between the tholeiitic and calcalkaline fields or, more rarely, in the tholeiitic field (Fig. 5).

Of interest is that in the pyroclastic flow $\mathrm{PF}_{3}$, along with predominant andesite-dacites (fragments, analysis 9 and matrix, analysis 8, see Table 2), juvenile fragments of basaltic andesites are present (analysis 4 in Table 2) which may point to the simultaneous presence of andesite-dacitic and andesite-basaltic melts inside the volcano and their mixing during the eruption process.

One of the distinctive features of the petrographic composition of the rocks of Kizimen is the presence of nonequilibrium mineral associations: simultaneous 
Table 2

Representative chemical analysis of Kizimen Volcano rocks

\begin{tabular}{|c|c|c|c|c|c|c|c|c|c|c|c|c|}
\hline \multirow[t]{2}{*}{ Sample No.: } & 1 & 2 & 3 & 4 & 5 & 6 & 7 & 8 & 9 & 10 & 11 & 12 \\
\hline & $7 \mathrm{~K}$ & $35 \mathrm{~K} / 2$ & $26 \mathrm{Ka}$ & $22 \mathrm{~K} / 2$ & HK & $40 \mathrm{~K}$ & $34 \mathrm{~K} / 2$ & $18 \mathrm{~K} / 4$ & $22 \mathrm{~K} / 1$ & $31 \mathrm{~K} / 2$ & $6 \mathrm{~K}$ & $35 \mathrm{~K} / 1$ \\
\hline $\mathrm{SiO}_{2}$ & 51.70 & 54.44 & 54.52 & 55.90 & 57.66 & 57.96 & 59.52 & 61.14 & 61.45 & 61.56 & 63.38 & 63.72 \\
\hline $\mathrm{TiO}_{2}$ & 1.00 & 0.93 & 1.11 & 1.01 & 0.81 & 0.89 & 0.70 & 0.72 & 0.73 & 0.69 & 0.62 & 0.58 \\
\hline $\mathrm{Al}_{2} \mathrm{O}_{3}$ & 16.95 & 18.79 & 17.63 & 17.40 & 17.94 & 16.80 & 17.08 & 16.74 & 16.40 & 15.99 & 15.60 & 16.94 \\
\hline $\mathrm{Fe}_{2} \mathrm{O}_{3}$ & 3.19 & 2.79 & 3.62 & 5.00 & 2.05 & 8.20 & 2.47 & 2.69 & 2.70 & 2.88 & 1.80 & 2.24 \\
\hline $\mathrm{FeO}$ & 7.26 & 5.50 & 6.19 & 3.62 & 4.68 & - & 3.63 & 3.51 & 3.23 & 3.46 & 3.60 & 2.85 \\
\hline $\mathrm{MgO}$ & 0.15 & 0.18 & 0.12 & 0.15 & 0.13 & 0.14 & 0.11 & 0.13 & 0.12 & 0.12 & 0.10 & 0.11 \\
\hline $\mathrm{MnO}$ & 6.68 & 4.13 & 3.58 & 4.20 & 3.61 & 3.60 & 2.48 & 2.59 & 2.60 & 2.43 & 2.20 & 1.84 \\
\hline $\mathrm{CaO}$ & 8.32 & 7.91 & 8.20 & 8.00 & 7.37 & 6.80 & 5.92 & 6.07 & 6.20 & 5.55 & 5.10 & 5.70 \\
\hline $\mathrm{Na}_{2} \mathrm{O}$ & 2.92 & 3.31 & 3.17 & 3.32 & 3.26 & 3.43 & 3.31 & 4.46 & 3.60 & 3.19 & 3.24 & 3.68 \\
\hline $\mathrm{K}_{2} \mathrm{O}$ & 1.00 & 1.20 & 1.25 & 1.13 & 1.35 & 1.37 & 1.54 & 1.3 & 1.32 & 1.78 & 1.73 & 1.49 \\
\hline $\mathrm{H}_{2} \mathrm{O}^{+}$ & 0.10 & - & 0.02 & - & - & - & 0.84 & 0.28 & - & 0.54 & - & 0.26 \\
\hline $\mathrm{H}_{2} \mathrm{O}^{+}$ & 0.54 & - & 0.28 & - & 0.43 & - & 0.76 & 0.87 & - & 1.60 & - & 0.12 \\
\hline $\mathrm{P}_{2} \mathrm{O}_{5}$ & 0.26 & 0.12 & 0.09 & 0.34 & 0.16 & 0.09 & 0.14 & 0.04 & 0.26 & 0.14 & 0.17 & 0.17 \\
\hline LOI & - & - & - & 0.53 & - & 0.32 & 1.36 & - & 0.91 & 0.37 & 2.84 & 0.14 \\
\hline$\Sigma$ & 100.07 & 99.70 & 99.78 & 100.60 & 99.63 & 99.60 & 99.86 & 99.87 & 99.52 & 100.30 & 100.28 & 99.84 \\
\hline
\end{tabular}

Note: $1=$ lava of Tamara cinder cone. Kizimen volcano rocks: $2-6,8,9-$ cycle IV; $2,3,5,6=$ lava, 4, 8, $9=\mathrm{PF}_{3}$ material $(4,9-j u v e n i l e$ fragments, $8=$ matrix). 7,10 -cycle KZII; $7=$ coarse pumiceous tephra, $10=$ fragments from $\mathrm{PF}_{2} ; 11,12-$ cycle $\mathrm{KZI}: 11=$ pumice lapilli from $\mathrm{PF}$, $12=$ lava. Analyses 2, 3, 5, 7, 8, 10, 12 were made at the Central Chemical Lab. Institute of Volcanology, remaining analyses at the Institute of Geochemistry, Irkutsk. Mineral microprobe analyses were made in samples 1, 3, 5, 12.

Table 3

Composition of plagioclase from Kizimen Volcano rocks

\begin{tabular}{|c|c|c|c|c|c|c|c|c|c|c|c|c|c|}
\hline & $((\mathrm{Pc})$ & $2(\mathrm{Pr})$ & $3(\mathrm{M})$ & $4(\mathrm{Pc})$ & $5(\mathrm{Pc})$ & $6(\mathrm{Pi})$ & $7(\mathrm{Pr})$ & $8(M)$ & $9(\mathrm{Pc})$ & $10(\mathrm{Pc})$ & $11(\operatorname{Pr})$ & $12(\mathrm{M})$ & $13(\mathrm{P})$ \\
\hline $\mathrm{SiO}_{2}$ & 47.99 & 52.95 & 53.01 & 46.63 & 56.23 & 48.66 & 51.85 & 53.34 & 46.75 & 56.23 & 51.60 & 54.43 & 55.81 \\
\hline $\mathrm{TiO}_{2}$ & 0.05 & 0.08 & 0.09 & 0.00 & 0.00 & 0.00 & 0.01 & 0.05 & 0.00 & 0.02 & 0.00 & 0.08 & 0.03 \\
\hline $\mathrm{Al}_{2} \mathrm{O}_{3}$ & 33.69 & 29.99 & 29.71 & 33.57 & 28.14 & 32.24 & 29.90 & 29.26 & 33.97 & 27.56 & 30.18 & 27.93 & 27.41 \\
\hline $\mathrm{FeO}$ & 0.71 & 1.09 & 1.14 & 0.65 & 0.29 & 0.67 & 0.80 & 0.98 & 0.56 & 0.29 & 0.69 & 1.05 & 0.29 \\
\hline $\mathrm{MnO}$ & 0.03 & 0.03 & 0.04 & 0.00 & 0.00 & 0.00 & 0.01 & 0.03 & 0.00 & 0.01 & 0.00 & 0.05 & 0.02 \\
\hline $\mathrm{MgO}$ & 0.11 & 0.13 & 0.10 & 0.00 & 0.00 & 0.00 & 0.00 & 0.13 & 0.00 & 0.01 & 0.03 & 0.13 & 0.22 \\
\hline $\mathrm{CaO}$ & 16.23 & 12.76 & 12.43 & 17.15 & 10.27 & 15.44 & 13.20 & 12.16 & 17.11 & 9.65 & 12.27 & 10.81 & 9.79 \\
\hline $\mathrm{Na}_{2} \mathrm{O}$ & 1.94 & 3.72 & 4.00 & 1.84 & 5.69 & 2.73 & 4.06 & 4.13 & 1.82 & 5.69 & 4.03 & 4.63 & 5.59 \\
\hline $\mathrm{K}_{2} \mathrm{O}$ & 0.08 & 0.27 & 0.28 & 0.02 & 0.23 & 0.10 & 0.18 & 0.23 & 0.00 & 0.28 & 0.15 & 0.41 & 0.27 \\
\hline$\Sigma$ & 100.83 & 101.02 & 100.79 & 99.87 & 100.81 & 99.84 & 99.99 & 100.32 & 100.22 & 99.74 & 99.96 & 99.49 & 99.23 \\
\hline An & 81.8 & 64.4 & 62.2 & 83.7 & 49.2 & 75.3 & 63.5 & 61.0 & 83.8 & 47.6 & 64.0 & 54.9 & 48.4 \\
\hline $\mathrm{Ab}$ & 17.7 & 34.0 & 36.1 & 16.1 & 49.7 & 24.1 & 35.4 & 37.6 & 16.2 & 50.7 & 35.2 & 42.6 & 50.0 \\
\hline Or & 0.5 & 1.6 & 1.7 & 0.1 & 1.4 & 0.6 & 1.1 & 0.4 & 0.0 & 1.7 & 0.8 & 2.5 & 1.6 \\
\hline $\mathrm{n}$ & 4 & 4 & 6 & 7 & 10 & 4 & 7 & 5 & 9 & 13 & 8 & 5 & 10 \\
\hline
\end{tabular}

Note: $1-3=$ basalt; $4-8=$ basaltic andesite; $9-12=$ andesite; 13 -dacite.

In Tables 3-6: $n=$ number of analyses; symbols after analyses numbers: $\mathrm{P}=$ phenocrysts $(\mathrm{Pc}=$ cores, $\mathrm{Pr}=$ rims, $\mathrm{Pi}=$ intermediate zones), $\mathrm{M}=$ microlites, Incl $=$ inclusions in phenocrysts.

Analyses were made at X-ray microprobe Camebax by G.P. Ponomarev and V.V. Ananjev (Institute of Volcanology). 


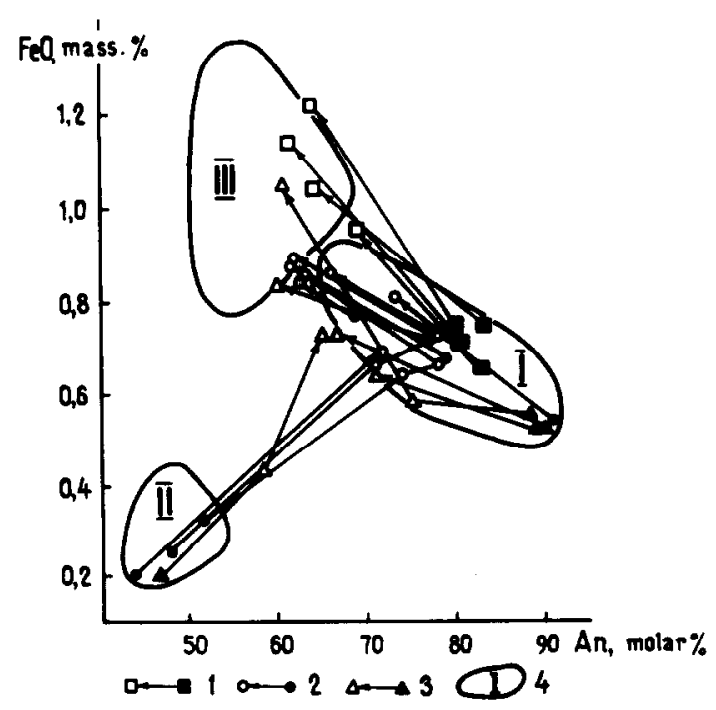

Fig. 7. Variations in $\mathrm{FeO}$ content in zonal plagioclase phenocrysts from the rocks of Kizimen volcano. $l=$ basalt, 2 = basaltic andesite, $3=$ andesite. Black symbols $=$ crystal cores, open $=$ intermediate and marginal parts. Arrows show the compositional variations from core to rim in individual crystals. $I-I I I=$ plagioclase compositional fields; $I=$ phenocrysts from basalt, $I I=$ phenocrysts from dacite, $I I I=$ microlites from the rocks of basic-intermediate composition.

presence of quartz phenocrysts and magnesian-rich olivines in andesites and dacites, occurrence of plagioclase phenocrysts of strongly different composition in basaltic andesites, widespread occurrence of orthopy- roxene reaction rims on olivine, high $\mathrm{Mg}$ content of orthopyroxene microlites as compared to the phenocrysts in andesites, etc. Of interest is also the constant occurrence of amphibole phenocrysts in all types of rocks from dacites to basaltic andesites.

Let us consider these peculiarities in more detail using data on the composition of the minerals (Tables 3-6). In basaltic andesites and andesites two groups of plagioclase phenocrysts are distinguishable: one with cores of bytownite $\left(\mathrm{An}_{68-91}\right)$ as in basalt, and the other with cores of andesine-labradorite composition $\left(\mathrm{An}_{44}\right.$ ${ }_{55}$ ) as in dacite. The outer zone of the phenocrysts of the two groups are similar in composition $\left(\mathrm{An}_{47-72}\right.$ and $\mathrm{An}_{49-74}$, respectively) and resemble the plagioclase microlites $\left(\mathrm{An}_{50-66}\right)$, occupying in general an intermediate position, between the first and the second groups of cores (Fig. 6, Table 3). Occasionally, sodic cores are surrounded by intermediate zones of calcic plagioclase $\left(\mathrm{An}_{63-72}\right)$ with typical "sieve-like" matrix due to small inclusions of glass.

The presence of two discrete groups of plagioclase phenocryst cores in basaltic andesites and andesites is distinctly seen from the proportion of $\mathrm{FeO}$ and $\mathrm{An}$ in them (Fig. 7). Sodic plagioclase in these rocks lies in the field of dacitic plagioclase and has low concentrations of $\mathrm{FeO}(0.2-0.4 \mathrm{wt} . \%)$, whereas calcic plagioclase, in the field of basaltic plagioclase, is characterized by increased concentrations of $\mathrm{FeO}(0.5-$

Table 4

Composition of olivines and amphiboles from Kizimen volcano rocks

\begin{tabular}{|c|c|c|c|c|c|c|c|c|}
\hline & $1(P c)$ & $2(\mathrm{Pr})$ & $3(\mathrm{Pc})$ & $4(\mathrm{Pr})$ & $5(\mathrm{Pc})$ & $6(\mathrm{Pc})$ & $7(\mathrm{P})$ & $8(\mathrm{M})$ \\
\hline $\mathrm{SiO}_{2}$ & 39.75 & 38.16 & 38.58 & 37.90 & 38.13 & 38.22 & 45.79 & 45.79 \\
\hline $\mathrm{TiO}_{2}$ & 0.04 & 0.05 & 0.00 & 0.02 & 0.03 & 0.04 & 1.77 & 1.82 \\
\hline $\mathrm{Al}_{2} \mathrm{O}_{3}$ & 0.05 & 0.04 & 0.00 & 0.01 & 0.04 & 0.03 & 9.00 & 9.24 \\
\hline $\mathrm{Fe}_{2} \mathrm{O}_{3}$ & 0.05 & 0.02 & 0.01 & 0.01 & 0.01 & 0.01 & 0.02 & 0.00 \\
\hline $\mathrm{FeO}$ & 17.78 & 26.42 & 20.73 & 26.93 & 22.17 & 21.27 & 13.28 & 14.24 \\
\hline $\mathrm{MnO}$ & 0.27 & 0.49 & 0.29 & 0.47 & 0.36 & 0.55 & 0.37 & 0.43 \\
\hline $\mathrm{MgO}$ & 42.37 & 34.88 & 40.18 & 34.43 & 37.87 & 38.63 & 13.61 & 13.14 \\
\hline $\mathrm{CaO}$ & 0.09 & 0.18 & 0.09 & 0.17 & 0.14 & 0.04 & 10.98 & 10.99 \\
\hline $\mathrm{Na}_{2} \mathrm{O}$ & 0.00 & 0.01 & 0.01 & 0.05 & 0.01 & 0.02 & 1.58 & 1.51 \\
\hline $\mathrm{K}_{2} \mathrm{O}$ & 0.00 & 0.00 & 0.00 & 0.00 & 0.00 & 0.00 & 0.34 & 0.42 \\
\hline$\Sigma$ & 100.40 & 100.24 & 99.83 & 99.99 & 98.75 & 98.81 & 96.74 & 97.61 \\
\hline f, at $\%$ & 19.1 & 30.4 & 22.6 & 31.0 & 25.0 & 24.1 & 36.1 & 38.5 \\
\hline$n$ & 7 & 7 & 7 & 7 & 7 & 3 & 5 & 1 \\
\hline
\end{tabular}

Note: $1-2=$ basalt; $3-4=$ basaltic andesite; $5=$ andesite; $6-8=$ dacite. $1-6=$ olivines; $7,8=$ amphiboles. 


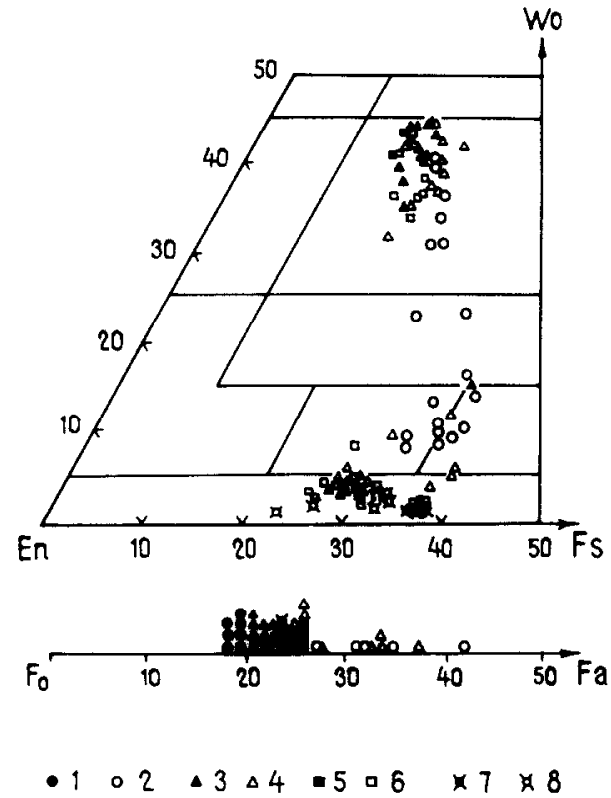

Fig. 8. Composition of olivines and pyroxenes from the rocks of Kizimen volcano. $12=$ basalt, $34=$ basaltic andesite; $56=$ andesite; $78=$ dacite. Black symbols designate the phenocryst cores; open, the microlites.

$0.9 \mathrm{wt} . \%)$. The microlites in rocks of the basalt-andesite series that have the maximum concentrations of $\mathrm{FeO}(0.75-1.35$ wt.\%) in Ca content occupy an intermediate position between these two fields. The composition of the outer zones incrusting the calcic plagioclase cores shifts to the field of microlites, while the composition of the "sieve-like" zones and the outer rims on cores of sodic plagioclase shift first into the field of the calcic cores and then again into the field of microlites.

The composition of the cores of olivine phenocrysts in basaltic andesites, andesites and dacites is similar, $\mathrm{Fo}_{73-79}$ (Table 4, Fig. 8). Commonly, in andesites and dacites and occasionally in basaltic andesites, olivine phenocrysts are surrounded by rims of orthopyroxene and magnetite which indicates the lack of equilibrium between this mineral and the respective melts. This is also supported by calculations after Roeder and Emslie (1970) according to which the value of the distribution coefficient $\left(K_{d}^{\mathrm{Fe}-\mathrm{Mg}}\right)$ ) exceeds the equilibrium values in dacites, andesites and calc-alkali basaltic andesites ( $K_{\mathrm{d}}$ in these rocks is $0.36,0.44$ and 0.35 , respectively); only in the tholeiitic basaltic andesites does the $K_{\mathrm{d}}$ value (0.31) correspond to equilibrium.

In many basaltic andesites and andesites with independent olivine phenocrysts, aggregates of olivine with calcic plagioclase (bytownite) occur. Occasionally, such olivine nodules are surrounded by clasts of decrystallized groundmass that are distinguished from clasts with colorless or grey glass, by the brownish color of the glass and its higher crystallinity. Finally, the cores of the olivine phenocrysts in the intermediate acid lavas are only slightly more ferrous than the phenocryst cores in basalt $\left(\mathrm{Fo}_{79.7-81.5}\right)$.

Amphibole phenocrysts which in dacitic andesites and dacites are not at all altered, in basaltic andesites and basic andesites are wholly dissociated and replaced by an aggregate of subcalcic augite $\left(\mathrm{Fo}_{24-27} \mathrm{En}_{42-53}\right.$ $\left.\mathrm{Fs}_{22-31}\right)$, andesine-labradorite $\left(\mathrm{An}_{43-62}\right)$ and titanomagnetite. That means that presumably in basaltic andesites and andesitic melts, amphiboles are also a non-equilibrium phase.

The compositions of orthopyroxene phenocrysts in andesites and dacites are identical in $\mathrm{Fe}$ and alumina content but differ sharply in these parameters from phe-

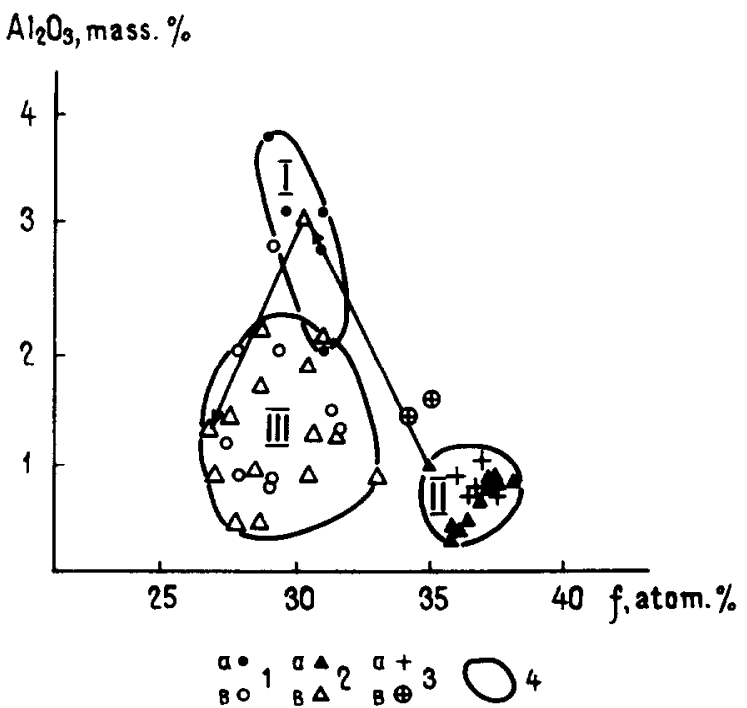

Fig. 9. Variations in $\mathrm{Fe}$ and alumina contents in orthopyroxenes from the rocks of Kizimen volcano. $1=$ basaltic andesite; $2=$ andesite; $3=$ dacite. $(a=$ phenocrysts, $b=$ microlites and rims of zonal phenocrysts $) . I-I I I=$ orthopyroxene composition fields: $I=$ phenocrysts from basaltic andesites; $I I=$ phenocrysts from andesites and dacites, $I I I=$ microlites from basaltic andesites and andesites 
Table 5

Composition of pyroxenes from Kizimen Volcano rocks

\begin{tabular}{lccccccccccccccc}
\hline & $\mathrm{q}(\mathrm{M})$ & $2(\mathrm{M})$ & $3(\mathrm{M})$ & $4(\mathrm{P})$ & $5(\mathrm{P})$ & $6(\mathrm{M})$ & $7(\mathrm{M})$ & $8(\mathrm{P})$ & $9(\mathrm{P})$ & $10(\mathrm{Pi})$ & $11(\mathrm{M})$ & $12(\mathrm{M})$ & $13(\mathrm{M})$ & $14(\mathrm{P})$ & $15(\mathrm{M})$ \\
\hline $\mathrm{SiO}_{2}$ & 51.17 & 52.77 & 53.06 & 50.86 & 53.46 & 50.87 & 53.69 & 50.54 & 53.64 & 54.05 & 50.27 & 52.40 & 53.09 & 52.47 & 53.20 \\
$\mathrm{TiO}_{2}$ & 0.91 & 0.61 & 0.44 & 0.77 & 0.18 & 0.90 & 0.26 & 0.82 & 0.13 & 0.30 & 0.85 & 0.35 & 0.29 & 0.13 & 0.24 \\
$\mathrm{Al}_{2} \mathrm{O}_{3}$ & 3.03 & 1.63 & 1.18 & 3.61 & 2.98 & 3.65 & 1.71 & 3.83 & 0.80 & 1.32 & 3.82 & 0.52 & 1.53 & 0.83 & 1.50 \\
$\mathrm{Cr}_{2} \mathrm{O}_{3}$ & 0.02 & 0.02 & 0.01 & 0.02 & 0.01 & 0.02 & 0.00 & 0.03 & 0.03 & 0.00 & 0.02 & 0.00 & 0.00 & 0.00 & 0.03 \\
$\mathrm{FeO}$ & 12.47 & 17.79 & 20.26 & 9.65 & 17.46 & 10.64 & 17.28 & 9.36 & 21.66 & 15.62 & 10.34 & 16.40 & 17.52 & 21.63 & 20.09 \\
$\mathrm{MnO}$ & 0.43 & 0.62 & 0.78 & 0.30 & 0.63 & 0.35 & 0.67 & 0.34 & 1.17 & 0.52 & 0.40 & 0.46 & 0.56 & 1.12 & 0.84 \\
$\mathrm{MgO}$ & 14.42 & 16.81 & 19.13 & 14.28 & 23.43 & 13.89 & 23.89 & 14.41 & 21.83 & 24.74 & 14.33 & 22.25 & 23.84 & 21.92 & 22.11 \\
$\mathrm{CaO}$ & 16.84 & 10.27 & 5.18 & 19.51 & 1.47 & 18.46 & 2.06 & 19.37 & 0.75 & 1.87 & 18.26 & 3.91 & 1.84 & 0.67 & 1.26 \\
$\mathrm{Na} \mathrm{O}_{2} \mathrm{O}$ & 0.22 & 0.11 & 0.04 & 0.18 & 0.10 & 0.16 & 0.00 & 0.19 & 0.02 & 0.01 & 0.11 & 0.01 & 0.02 & 0.01 & 0.01 \\
$\mathrm{~K}_{2} \mathrm{O}$ & 0.02 & 0.02 & 0.03 & 0.00 & 0.08 & 0.02 & 0.07 & 0.01 & 0.00 & 0.00 & 0.02 & 0.00 & 0.02 & 0.00 & 0.00 \\
& & & & & & & & & & & & & & \\
$\Sigma$ & 99.54 & 100.63 & 100.11 & 99.19 & 99.81 & 99.04 & 99.62 & 98.90 & 100.01 & 98.42 & 98.42 & 98.31 & 98.71 & 98.78 & 99.28 \\
$\mathrm{Wo}$ & 35.8 & 21.4 & 10.7 & 41.5 & 3.1 & 40.0 & 4.2 & 41.2 & 1.5 & 3.8 & 39.2 & 8.2 & 3.8 & 1.4 & 2.6 \\
$\mathrm{En}$ & 42.7 & 48.6 & 55.2 & 42.2 & 67.6 & 41.5 & 68.1 & 42.7 & 62.1 & 70.4 & 42.8 & 64.9 & 67.8 & 62.3 & 63.6 \\
$\mathrm{Fs}$ & 21.5 & 40.0 & 34.1 & 16.3 & 29.3 & 18.4 & 27.7 & 16.1 & 36.4 & 25.6 & 18.0 & 26.9 & 28.4 & 36.3 & 33.8 \\
$n$ & 8 & 3 & 9 & 10 & 5 & 13 & 5 & 4 & 8 & 1 & 7 & 1 & 171 & 6 & 2 \\
\hline
\end{tabular}

Note: $1-3=$ basalt; $4-7=$ basaltic andesite; $8-13$-andesite; $14-15=$ dacite.

$1,4,6,8,11=$ clinopyroxenes; 2 = subcalcic augites; 3,12 = pigeonites; $5,7,9,10,13-15=$ orthopyroxenes.

nocrysts in basaltic andesites; the compositions of orthopyroxene microlites in the andesites and basaltic andesites totally overlap (Fig. 9, Table 5). At the same time, orthopyroxene microlites in dacites are slightly, and in andesites strongly, more magnesian and generally have higher alumina content than the phenocrysts, whereas in basaltic andesites the microlites are close to the phenocrysts in their Fe content but differ in alumina content, which is noticeably lower in microlites. Orthopyroxene phenocrysts are commonly not zoned, but occasionally in andesites zoned crystals occur in which the composition of the intermediate zones shifts in $\mathrm{Fe}$ and alumina content into the field of basaltic andesites and that of the outer zones, into the microlite field ( see

Table 6

Composition of oxide ore phases in Kizimen Volcano rocks

\begin{tabular}{|c|c|c|c|c|c|c|c|c|c|c|c|c|c|c|}
\hline & 1 (Incl) & 2 (Incl) & $3(P)$ & $4(P)$ & $5(\mathrm{P})$ & $6(\mathrm{M})$ & 7 (Incl) & 8 (Incl) & $9($ Incl) & $10($ Incl $)$ & 11 (Incl) & $12(\mathrm{M})$ & $13(P)$ & $14(P)$ \\
\hline $\mathrm{SiO}_{2}$ & - & - & 0.12 & 0.00 & 0.00 & 0.17 & 0.01 & 0.00 & 0.00 & 0.00 & 0.00 & 0.05 & 0.01 & 0.01 \\
\hline $\mathrm{TiO}_{2}$ & 1.42 & 5.07 & 11.54 & 12.15 & 44.00 & 13.61 & 7.52 & 6.29 & 36.43 & 12.16 & 44.44 & 11.87 & 5.96 & 39.73 \\
\hline $\mathrm{Al}_{2} \mathrm{O}_{3}$ & 24.79 & 11.37 & 2.24 & 1.44 & 0.00 & 1.51 & 3.21 & 2.00 & 0.00 & 1.33 & 0.00 & 2.06 & 2.15 & 0.50 \\
\hline $\mathrm{Cr}_{2} \mathrm{O}_{3}$ & 21.92 & 14.67 & 0.10 & 0.00 & 0.00 & 0.08 & 0.09 & 0.06 & 0.00 & 0.00 & 0.00 & 0.02 & 0.06 & 0.03 \\
\hline $\mathrm{Fe}_{2} \mathrm{O}_{3}$ & 19.21 & 33.43 & 45.39 & 45.84 & 19.82 & 41.29 & 53.36 & 57.54 & 31.85 & 45.40 & 17.71 & 39.85 & 56.53 & 24.96 \\
\hline $\mathrm{FeO}$ & 23.10 & 28.75 & 38.93 & 39.66 & 33.75 & 40.76 & 34.80 & 35.36 & 28.13 & 40.12 & 34.91 & 44.57 & 35.17 & 31.89 \\
\hline $\mathrm{MnO}$ & 0.34 & 0.44 & 0.44 & 0.50 & 0.55 & 0.52 & 0.50 & 0.45 & 0.80 & 0.44 & 0.57 & 0.52 & 0.50 & 0.68 \\
\hline $\mathrm{MgO}$ & 9.10 & 5.53 & 1.92 & 1.87 & 2.95 & 1.61 & 2.68 & 1.59 & 2.26 & 1.50 & 2.51 & 1.40 & 1.13 & 1.98 \\
\hline $\mathrm{CaO}$ & - & - & 0.07 & 0.00 & 0.00 & 0.16 & 0.09 & 0.00 & 0.00 & 0.00 & 0.00 & 0.11 & 0.01 & 0.01 \\
\hline $\mathrm{Na}_{2} \mathrm{O}$ & - & - & 0.01 & 0.00 & 0.00 & 0.04 & 0.00 & 0.00 & 0.00 & 0.00 & 0.00 & 0.00 & 0.01 & 0.00 \\
\hline $\mathrm{K}_{2} \mathrm{O}$ & - & $=$ & 0.00 & 0.00 & 0.00 & 0.00 & 0.00 & 0.00 & 0.00 & 0.00 & 0.00 & 0.00 & 0.00 & 0.00 \\
\hline$\Sigma$ & 99.83 & 99.26 & 100.76 & 101.47 & 101.07 & 99.74 & 102.26 & 103.29 & 99.26 & 100.95 & 100.14 & 100.45 & 101.54 & 99.77 \\
\hline$f$ & 59.2 & 74.4 & 92.0 & 92.3 & 86.5 & 93.5 & 87.9 & 92.6 & 87.5 & 93.8 & 88.6 & 94.2 & 94.6 & 90.2 \\
\hline$n$ & 14 & 14 & 6 & 2 & 2 & 11 & 5 & 1 & 1 & 1 & 1 & 2 & 4 & 3 \\
\hline
\end{tabular}

Note: $1,2=$ basalt, inclusion in olivine; $3-6=$ basaltic andesite $(4,5=$ grain aggregate $) ; 7-12=$ andesite $(7=$ inclusion in clinopyroxene, 8 , $9=$ inclusion in the orthopyroxene core, $10,11=$ aggregate of inclusions in the rim of the same phenocryst), 13, 14=dacite. 


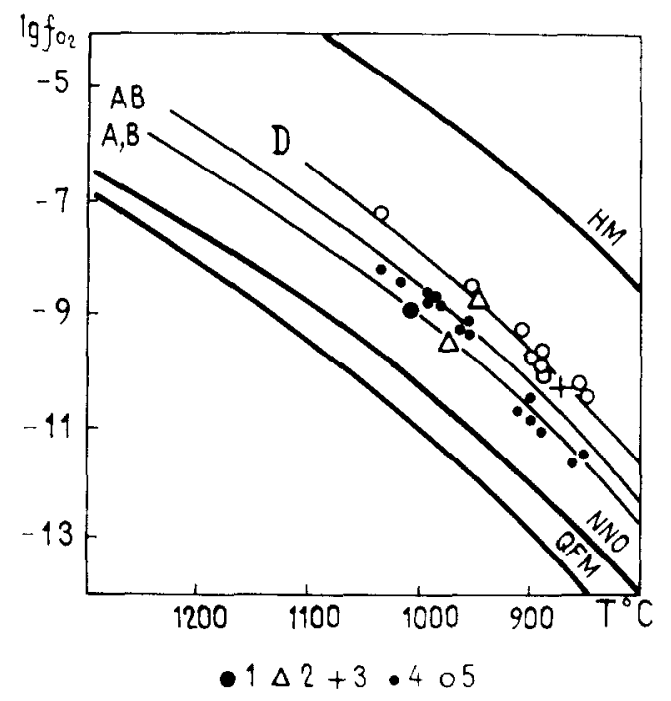

Fig. 10. Oxygen fugacity and crystallization temperature of oxide ore phases in the rocks of Kizimen volcano. $l=$ basaltic andesite, $2=$ andesite; $3=$ dacite, 45 = lavas of Quaternary volcanoes of Kamchatka and Kuriles: $4=$ two-pyroxene, $5=$ amphibole- and biotitebearing. The calculated curves are for: $B=$ basalt; $A B=$ basaltic andesite, $A=$ andesite; $D=$ dacite.

Fig. 9). In many andesites the orthopyroxene phenocrysts have rims of clinopyroxene. This allows us to infer that orthopyroxene phenocrysts in andesites are non-equilibrium as distinct from basaltic andesites where such equilibrium can be expected.

Clinopyroxene phenocrysts were not detected in dacites; instead there arc widcspread occurrences of amphibole. In basaltic andesites and andesites the clinopyroxenes are identical in composition. Clinopyroxene microlites in both types of rocks are only a little bit less calcic and more ferrous that the phenocrysts; however, in basaltic andesites along with clino- and orthopyroxene microlites there are occurrences of pigeonite which is rare in the andesites (Table 5, see Fig. 8). Occasionally, in basaltic andesites, pigeonites are covered by small clinopyroxene phenocrysts. In basalt clino- and orthopyroxene phenocrysts are absent, and among the microlites clinopyroxene and pigeonite occur approximately in the same proportion with rare occurrences of subcalcic augite.

Protocrysts of the ore phase in basalt are represented by $\mathrm{Al}-\mathrm{Cr}$-Fe spinel and $\mathrm{Cr}$-magnetite that occur in the olivine phenocrysts. Titanomagnetite and rarer ilmenite are represented by phenocrysts and inclusions in the pyroxene of the basaltic andesites, andesites and dacites (Table 6). The $\mathrm{TiO}_{2}$ content in titanomagnetite gradually decreases from basaltic andesites through andesites to dacite and is 9-14, 6-12 and 5-7 wt.\%, respectively. In andesites the titanomagnetite in the cores of the pyroxene phenocrysts contains $6-12 \mathrm{wt} . \%$ of $\mathrm{TiO}_{2}$ whereas in the rims it contains $9-12 \mathrm{wt} . \%$.

The value of $f_{\mathrm{O}_{2}}$ for magnetite-ilmenite aggregate from phenocrysts in the basaltic andesite calculated after Powell and Powell (1977) is approximately an order higher than that of the NNO buffer and falls on the curve calculated from bulk composition of basalt and andesite according to Kilinc et al., (1983), whereas

Table 7

Results of mass-balanced calculations for fractional crystallization model for Kizimen Volcano rocks

\begin{tabular}{|c|c|c|c|c|c|c|c|}
\hline \multirow{2}{*}{$\begin{array}{l}\text { Rocks pairs } \\
\text { Fraction of fractionating } \\
\text { mineral phases (mass.\%) }\end{array}$} & \multirow{2}{*}{$\begin{array}{c}\begin{array}{l}\text { Basalt-basaltic } \\
\text { andesite }\end{array} \\
10.0 \mathrm{Ol} \\
15.5 \mathrm{Pl} \\
-2.8 \mathrm{Sp} \\
2.7 \mathrm{Mt}_{\mathrm{cr}}\end{array}$} & $\begin{array}{l}\text { Basalt-andesite } \\
11.1 \mathrm{OI} \\
23.0 \mathrm{Pl}\end{array}$ & $\frac{\text { Basalt-dacite }}{14.6 \mathrm{OI}}$ & \multicolumn{2}{|c|}{ Basaltic andesite-andesite } & \multicolumn{2}{|c|}{ Andesite-dacite } \\
\hline & & $\begin{array}{c}11.1 \mathrm{Ol} \\
23.0 \mathrm{Pl} \\
-9.5 \mathrm{Sp} \\
11.6 \mathrm{Mr}^{-11}\end{array}$ & $\begin{array}{c}14.6 \mathrm{OI} \\
34.5 \mathrm{PI} \\
-13.0 \mathrm{Sp} \\
16.8 \mathrm{Mt}_{\mathrm{tr}}\end{array}$ & $\begin{array}{l}-0.5 \mathrm{OI} \\
5.4 \mathrm{Cpx} \\
2.2 \mathrm{Pl}_{1} \\
7.6 \mathrm{Pl}_{2} \\
4.5 \mathrm{Mo}_{\mathrm{ti}}\end{array}$ & $\begin{array}{l}-1.1 \mathrm{Opx} \\
5.5 \mathrm{Cpx} \\
1.9 \mathrm{Pl}_{1} \\
7.3 \mathrm{Pl}_{2} \\
4.6\left(\mathrm{Mt}_{\mathrm{ti}}\right.\end{array}$ & $\begin{array}{l}4.5 \mathrm{Ol} \\
3.5 \mathrm{Cpx} \\
11.8 \mathrm{Pl}_{1} \\
6.2 \mathrm{Pl}_{2} \\
2.2 \mathrm{Mt}_{\mathrm{ij}}\end{array}$ & $\begin{array}{l}\text { 8.6 Opx } \\
\text { 3.3 Cpx } \\
11.5 \mathrm{Pl}_{1} \\
11.7 \mathrm{Pl}_{2} \\
1.7 \mathrm{Mt}_{\mathrm{ts}}\end{array}$ \\
\hline $\begin{array}{l}\text { Fraction of the remaining melt } \\
\text { (mass. \%) }\end{array}$ & 73.3 & 62.2 & 45.4 & 81.1 & 82.1 & 71.0 & 61.8 \\
\hline Sum of squares of differences & 0.54 & 1.08 & 1.60 & 0.05 & 0.03 & 0.13 & 0.26 \\
\hline
\end{tabular}

Note: analyses of rock composition are given in Table $2(\mathrm{l}=$ basalt, $3=$ basaltic andesite. $5=$ andesite, $12=$ dacite $)$, those of minerals in Tables 3-6. Data for phenocrysts composition were used for calculation. Symbols for minerals: $\mathrm{Ol}=$ olivine, $\mathrm{C} p \mathrm{x}=$ clinopyruxene, Opx $=$ orthopyroxene, $\mathrm{PI}_{1}=$ calcic plagioclase, $\mathrm{Pl}_{2}=$ sodic plagioclase, $\mathrm{Sp}=$ spinel, $\mathrm{Mt} \mathrm{t}_{\mathrm{cr}}=\mathrm{Cr}$-magnetite, $\mathrm{Mt}_{1 \mathrm{i}}=$ Ti-magnetite, " - " before mineral phase means that it must accumulate in the remaining melt. 
the $f_{\mathrm{O}_{2}}$ value for magnetite-ilmenite pairs in dacite is approximately an order of magnitude higher and lies on the curve calculated for the bulk composition of this rock. Calculations of $F_{\mathrm{O}_{2}}$ for magnetite-ilmenite pairs from the core and rim zones of orthopyroxene phenocrysts in andesite yield different values corresponding to the dacite curve for the former $t$ and to the basaltic andesite curve for the latter (Fig. 10).

The origin of non-equilibrium mineral associations in volcanic rocks can be diverse. They originate as a result of a sharp change in the $P-T$ conditions of crystallization of the melts, in the course of partial melting of the enclosing rocks or during mixing of melts. The latter variation appears more realistic for the rocks of Kizimen volcano.

Analysis of An and $\mathrm{FeO}$ content ratio in the plagioclase of basaltic andesites and andesites indicates that the sodic and calcic phenocryst cores of this mineral could have crystallized only from melts that differed in $\mathrm{Ca}$ and $\mathrm{Fe}$ content, whereas the outer zones of the phenocrysts with different core compositions crystallized from homogeneous melts which were alike in these parameters. The composition of these melts could have been dacite and basalt, since the sodic cores of the plagioclase in the basaltic andesites and andesites resemble the plagioclase in the dacite and the calcic cores resemble the plagioclase in the basalt.

This idea is supported by the joint presence of phenocrysts of magnesian-rich olivine and quartz in the andesite as well as by the presence of clasts of material different in composition and structure from the mesostasis of the host rocks around many olivine phenocrysts. One should bear in mind that the dacite in many cases also contains a small admixture of basaltic material which is evidenced by the presence of olivine grains. The higher $\mathrm{Mg}$ content of the orthopyroxene microlites compared to the phenocrysts in andesite and the occasionally observed reverse zonation of the phenocrysts of this mineral do not contradict the idea of mixing of melts. The hypothesis of mixing is supported by the different values of $f_{\mathrm{O}_{2}}$ obtained for magnetite-ilmenite pairs from the cores and rims of orthopyroxene phenocrysts in the andesite. And finally, according to a calculation by the least-squares method of the chemical composition of the rocks, the andesite (analysis 5, Table 2) can be obtained when $46.0 \%$ of dacite and $53.8 \%$ of basalt are mixed (Table 2, analyses 12 and 1 , respectively).
The alternative hypothesis of the origin of the volcanic rocks by fractional crystallization of a basaltic magma calculated by the method of the least squares using the program MIN of A.D. Babansky (Institute of Mineralogy, Petrography and Geochemistry of Ore Deposits, USSR Academy of Sciences, Moscow) is hardly acceptable. In the case of basalt-andesite and basalt-dacite pairs, the sum of the square differences in the content of the rock-forming oxides is more than one, which is not acceptable according to the conditions of the calculations. Besides, in all variations of the calculations the remaining melt must accumulate spinel (Table 7). During fractionation of the basaltic andesite melt the andesite can be obtained only subject to accumulation in the remaining melt of a small amount of olivine $(0.5 \%)$ or orthopyroxene $(1.1 \%)$. And only for the andesite-dacite pair does the fractionation calculation yield quite satisfactory results (Table 7).

Accepting basaltic and dacitic melts as the primary components of the mixture, let us try to estimate some of their physico-chemical parameters, kceping in mind that during mixing the melts already contained crystalline phases. According to experimental data (Kadik et al., 1986), the crystallization of the amphibole-pyroxene andesite of the Klyuchevskoy group volcanoes in Kamchatka occurs at a water content of 5-6 wt.\% and that of the amphibole andesites, at 6-7 wt.\% of water, which corresponds to $P_{\mathrm{H}_{2} \mathrm{O}}$ of approximately $1.5-2.0$ $\mathrm{kbar}$ and $>2 \mathrm{kbar}$, respectively. If we apply these estimates to the pyroxene-amphibole dacites of Kizimen volcano, the $\mathrm{SiO}_{2}$ content of which is only a little higher than in the andesites (about $64 \%$ ), the crystallization temperature of plagioclase in the rocks according to the Kudo-Weill plagioclase geothermometer (Kudo and Weill, 1970) will be $920^{\circ} \mathrm{C}$ (at $P_{\mathrm{H}_{2} \mathrm{O}}=2 \mathrm{kbar}$ ) and $960^{\circ} \mathrm{C}$ (at $P_{\mathrm{H}_{2} \mathrm{O}}=1.5 \mathrm{kbar}$ ) which is close to the upper temperature limit of stability of amphibole in andesitic (dacitic?) melts $\left(925 \pm 25^{\circ} \mathrm{C}\right.$ ) (Kadik et al., 1986).

Amphibole-plagioclase aggregates are occasionally observed in dacites, which supports the idea of their joint, or close in time, crystallization. The estimate of the oxygen fugacity from the magnetite-ilmenite geothermometer (Powell and Powell, 1977) and bulk composition of dacite (Kilinc et al., 1983) gives similar results (Fig. 10) and indicates that dacite melts crystallized at $f_{\mathrm{O}_{2}}$ two orders higher than the NNO buffer.

To estimate these parameters for basalt is more difficult. Calculation of the distribution coefficient of $\mathrm{Fe}$ 
and $\mathrm{Mg}$ between olivine and basaltic melt yields a value that exceeds the equilibrium one (Roeder and Emslie, 1970) $-K_{\mathrm{d}}=0.44$. However, if we accept that the degree of oxidation of $\mathrm{Fe}$ in the basalt originally was close to the generally accepted value for these melts $\left(\mathrm{Fe}_{2} \mathrm{O}_{3} / \mathrm{FeO}=0.15\right)$, then the value of the newly calculated distribution coefficient turns out to correspond to the equilibrium one $\left(K_{\mathrm{d}}=0.305\right)$ and the curve of oxygen fugacity calculated for basalt is close to the NNO buffer (Fig. 10). On such an assumption the temperature of crystallization of olivine from the basaltic melt can be estimated based on the nomogram of Roeder and Emslie (1970) as $1165^{\circ} \mathrm{C}$. Similar values of the crystallization tempcraturc of olivine $\left(1146^{\circ} \mathrm{C}\right)$ were obtained by using the olivine-spinel geothermometer (Jackson, 1973), which increases the probability of the assumption that was made. The temperature of crystallization of the plagioclase phenocryst cores obtained by the Kudo-Weill geothermometer (1970) and calculated for moderate values of $P_{\mathrm{H}_{2} \mathrm{O}}$ considerably exceeds the equilibrium temperature of olivine $\left(1292^{\circ} \mathrm{C}\right.$ at $P_{\mathrm{H}_{2} \mathrm{O}}=0.5 \mathrm{kbar}$ and $1257^{\circ} \mathrm{C}$ at $P_{\mathrm{H}_{2} \mathrm{O}}=1$ kbar). This calculation suggests that plagioclase crystallized earlier than olivine. If we assume that crystallization of these minerals took place at the same time at the temperature of $1145-1165^{\circ} \mathrm{C}$, then $P_{\mathrm{H}_{2} \mathrm{O}}$ of the melt must reach $2 \mathrm{kbar}$, which corresponds to an $\mathrm{H}_{2} \mathrm{O}$ content of $4.5 \mathrm{wt} . \%$ at this temperature (Kadik et al., 1971). Unfortunately, our observation of the polished sections give no grounds to judge the relative time of recrystallization of these minerals.

The fugacity of oxygen during crystallization of the basaltic melt was, possibly, one order higher than that of the NNO buffer, which follows from calculation of the bulk composition of basalt.

Therefore, in spite of some free assumptions we can suggest that the liquidus temperatures of the basaltic and dacitic melts differed by no less than $200^{\circ} \mathrm{C}$ and that the oxygen fugacity differed by an order of magnitude. The intrusion of the hot basaltic melt from the deep magma chamber into the shallow magma chamber of colder acid magma, that remained there after the previous stage of volcanism in this region, presumably caused its overheating, boiling and the subsequent eruption of the (mixed) melts that were reacting with cach other.

In this relation the following observations may be of interest:
(1) the presence in all studied rocks (except for basalt from the Tamara cone) of non-equilibrium mineral phases;

(2) the gradual increase in abundance of basic products of eruptions with time;

(3) the gradual decrease in the volume of volcanic products with time;

(4) the similar duration of each of the cycles of volcanic activity (2.0-3.5 thousand years) combined with the high productivity of the early stages of every cycle and low productivity of the late stages.

The first of these observations testifies to the fact that the rocks studied do not represent a "clean line" but are the products of a more or less protruded shift of magmatic melts. Therefore, the processes of mixing preceded the eruptions, and between the periods of intrusion of basaltic melts into the acid chamber there was a certain interval of time during which homogenization of the material occurred.

The variations in basicity of volcanic rocks with time generally correspond to the idea of gradual squeezing of the near-surface chamber with dacite magma by basaltic melts rising from greater depths, and as a result of this the proportion of the basaltic melt in the mixing products increased. Whereas during formation of the Stary Kizimen the role of basaltic melts was small and is testified only by the presence of olivine phenocrysts in the dacite and acid andesite, in combination with quartz phenocrysts and acid plagioclase, the composition of the volcanic products of Molodoy Kizimen corresponds to strongly hybrid rocks, non-equilibrium in mineral compositions of andesite and basaltic andesite, with a small proportion of acid rocks that appeared only at the initial stage of development of the volcano.

And finally, it is worthy of note that quartz-olivine andesite and dacitic andesite, similar to lavas from Kizimen as regards the other features of mineral composition, are known to be present at some other volcanoes of Kamchatka. They have been described at Diky Greben volcano (Ogorodov et al., 1978), Aag and Arik (Fedorov, 1972), Bolshoy and Tolmachev Dol (unpublished data by O.N. Volynets). Undoubtedly they represent the products of mixing of magmatic melts.

Although quartz-olivine rocks are rather rare, many of the intermediate calc-alkaline lavas from Kamchatka volcanoes contain plagioclase phenocrysts of sharply different composition and have orthopyroxene pheno- 
crysts with higher Fe content than the microlites, i.e. they bear the features of mixing established for the lavas from Kizimen volcano. This circumstance as well as the wide occurrence of heterotaxial lavas and pumice (Volynets, 1979) suggest that the process of mixing of magmatic melts is one of the most important in resolving the question of variety of the rocks.

\section{Future eruptions and volcanic hazards}

It is suggested that the long-term forecast of type and parameters of future eruptions, and volcanic hazards, can be based on the principles illustrated for this volcano and already tested for similar problems at other volcanoes (Melekestsev et al., 1989). They include discovering the regularities in the dynamics of the volcanic activity, specifying the stage of activity that characterize the volcano at present and as a consequence of this, determining the likely character and number of cruptions that may occur during the recent stage of the activity of the volcano.

One of the main and necessary conditions for this approach is a detailed complex reconstruction of the eruptive activity and of the evolution of the erupted material from the moment of origin of the volcano or, at least, during a long period of its life, which has been done in the previous chapters of this paper. In particular, it has been shown that in spite of the comparatively short time since its origin, Kizimen is a sufficiently mature structure. The Stary Kizimen volcano that had been actively forming during three eruptive cycles (KZI-KZIII) almost ceased its activity about 6000 years ago and in its place a new volcano originated after a 3000-year repose, the Molodoy Kizimen volcano. That is why the data obtained for the Molodoy Kizimen volcano is of great interest for forecasting future eruptions, namely, data on the characteristics and frequency of its early eruptions and their temporal variations, evolution of the composition and morphology of the erupted rocks, and productivity of the volcano at different stages up to present time. The enumerated characteristics and parameters of the eruptive activity to a great extent are controlled by "internal" processes directly related to the life of the magma chamber and the feeding mechanisms.

However, a volcanic hazard forecast must include and consider the other "external" factors which may seriously influence the course of future eruptions. In our opinion, these include first of all the features of recent morphology of the Kizimen edifice, and also the structural confinement of the volcano on the flank of the Shchapinsky graben, which is characterized by high seismic activity.

As has been mentioned above, the volcanic activity of Molodoy Kizimen started about 3000 years ago with a powerful explosion and mass ejection of juvenile pyroclastics of contrasting chemical composition, in which along with predominant acid andesites, a small amount of basaltic andesites was present. Then, during a long period (to approximately 1100 years ago) the activity of the volcano was related to the growth of an andesitic extrusive dome that formed in the crater. The formation of the dome was accompanied by outpouring of andesite lava flows and weak-to-moderate explosive activity.

About eleven hundred years ago a new explosion occurred that opened the series of eruptions of the last phase, cycle KZIV. However, for the first time in the history of the volcano, the explosion was not followed by ejection of significant volumes of pyroclastics. Instead, a small effusive dome grew in the crater and calm explosive-effusive activity started, the products of which were distinguished by the highest basicity of the chemical composition. During the last centuries only fumarolic activity was observed, with rare phreatic explosions (the last took place in 1928).

During the whole KZIV cycle the activity of Molodoy Kizimen volcano was characterized by low productivity and volcanic intensity, especially at the terminating stage of the cycle (Table 1).

Therefore, it looks like during the KZIV eruptive cycle, Molodoy Kizimen volcano repeated the history of Stary Kizimen anew: but it took it a period three times shorter, in association with a sharply decreased productivity and volcanic intensity, and higher basicity of chemical composition. If we proceed only from this, we can conclude that the activity of Molodoy Kizimen volcano is in the termination stage, or near its termination.

Then the long-term forecast of the parameters of the future eruptions of Molody Kizimen will be reasonably simple: during the oncoming decades and even centuries the volcanic regime typical of the previous 150 200 years will be preserved. It will be limited to fumarolic activity of variable intensity with rare small phre- 


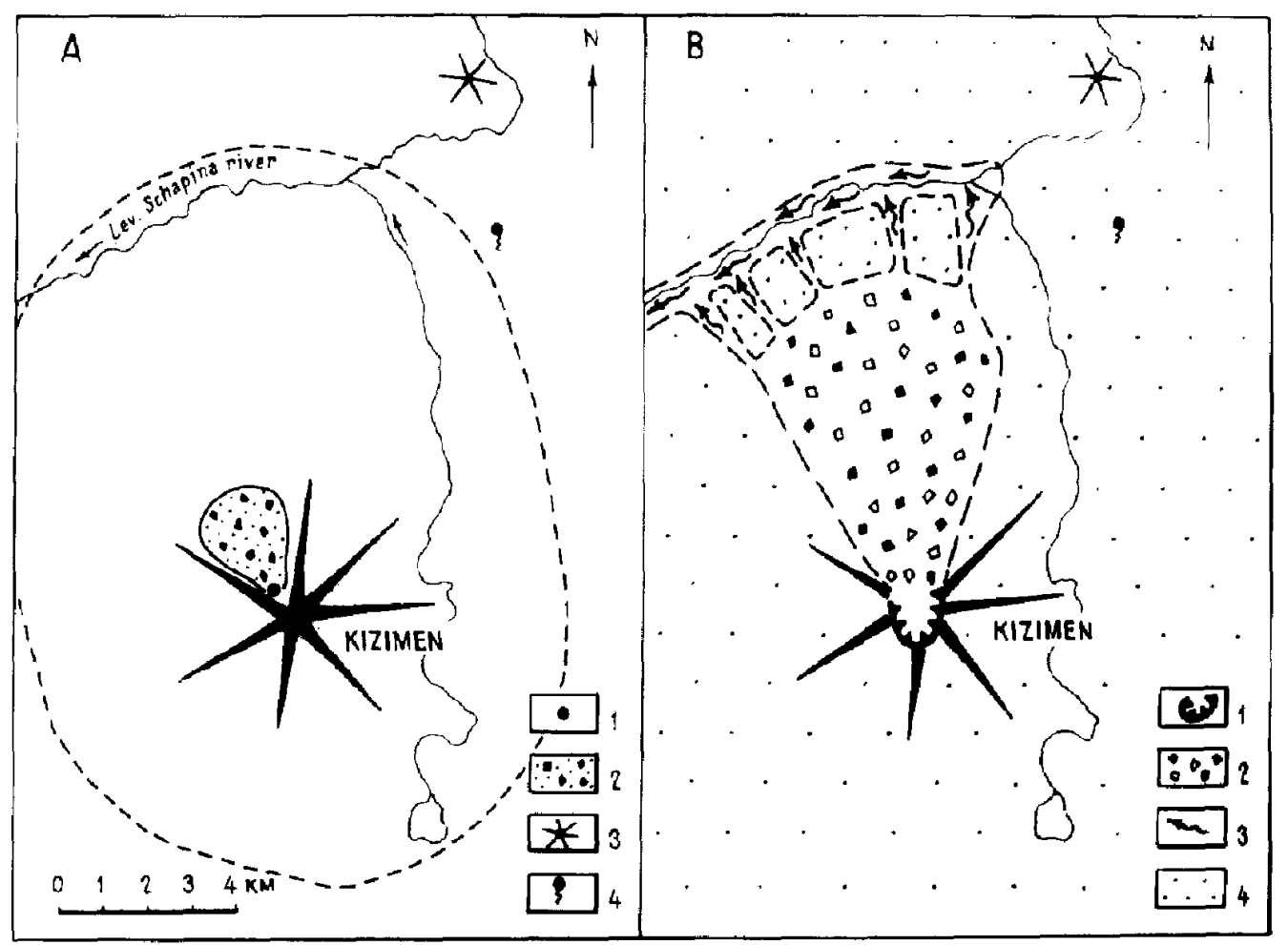

Fig. 11. A scheme for the inferred future volcanic hazard for Kizimen volcano. (A) Minimum event: $1=$ location of the eruptive center; $2=$ field of explosive deposits: $3=$ Tamara cinder cone; $4=U$ pper Shchapinsky thermal springs. The dotted line shows the ash fall zone with the thickncss of tephra over $0.1 \mathrm{~mm}$. (B) Maximum event: $l=$ collapse-explosive crater; $2=$ field of collapse-explosive deposits; $3=$ lahars; $4=z o n e$ of ash fall with thickness of tephra over $1 \mathrm{~cm}$.

atic explosions. The volcanic hazard will also he small, only involving areas within the volcanic edifice, at the moment of explosions (Fig. 11). Coarsely fragmented rubble from the volcanic explosions will be deposited close to the eruptive center and volcanic ash will fall on the cone of the volcano and at its foot. The thickness of the ash layer will vary from a few $\mathrm{cm}$ near the eruptive center to a few fractions of $\mathrm{mm}$ at distances of $5-10 \mathrm{~km}$ from it. The extent and direction of the ash fall zone will depend on the direction and velocity of the wind during the eruption. The collective volume of the material transported will not exceed $0.001 \mathrm{~km}^{3}$.

However, if we consider the "external" factors mentioned above, other variations of the long-term forecast of the character of volcanic eruptions and volcanic hazard are possible. Either each factor individually or their combination with volcanic processes proper can play a decisive role in influencing the course of events.

During destruction of the massive steep-sloped summit dome of Kizimen, as a result of explosion or col- lapse, the events can develop similar to those during eruptions at Bandai volcano, Japan, in 1888 or Mount St. Helens, USA, in 1980 (Voight et al., 1981; Glicken, 1988).

Such an explosion can be triggered even by comparatively brief plugging of the fumarolic vents for a few tens of years as a result of, say, earthquakes, because the recent fumaroles are characterized by very high activity. If the explosion takes place from beneath the base of the dome, where the fumaroles are locatcd, and is large, collapse of a portion of the dome will be almost obligatory. Of high probability also is seismo-tectonic collapse of the dome as a result of an intensity 9-10 earthquake beneath Shchapinsky graben close to Kizimen.

In all cases, independent of its causes, large collapse of the summit dome of Kizimen could initiate an eruption many times larger than the phreatic eruption of 1928. In terms of its parameters and geological effect it could be comparable with the eruption at Bandai 
volcano of 1888 , during which the volume of the volcano-seismo-tectonic collapse deposits amounted to $1.5 \mathrm{~km}^{3}$ and the volume of the explosive deposits to $0.011 \mathrm{~km}^{3}$ (Glicken, 1988). Juvenile material was absent. Such a volcano-seismo-tectonic collapse and subsequent explosion can also be caused by the intrusion of viscous magma beneath the floor of the dome, as happened for the catastrophic eruption at Mount St. Helens on 18 May 1980 (Lipman and Millineaux, 1980). The latter version cannot be excluded because on termination of the cycle KZIV a new fifth cycle may start as a result of injection of a new portion of magma into the feeding system of Kizimen.

This is related to the fact that Kizimen is located above the system of faults that border the large volcanotectonic depression to which the northern group of Kamchatkan volcanoes is confined (Melekestsev, 1980). During the last centuries this area has been characterized by high volcanic activity with catastrophic eruptions and large numbers of flank eruptions. A considerable mass on the order of $20 \times 10^{9} t$ of the juvenile material erupted here can easily testify to the beginning of regional activation of the magmatic process within the overall structure, including Kizimen volcano.

These eruptions could be highly hazardous, not only near the volcano but also far from it. Explosive and collapse deposits may cover a large area to the north at the foot of the volcano up to the valley of the Levaya Shchapina River, and the lahars could be several tens of $\mathrm{km}$ long (Fig. 11). The zone of the highest hazard will extend at least from the Upper Shchapinsky to the Lower Shchapinsky thermal springs. Tephra may cover an area of $10^{4}-10^{5} \mathrm{~km}^{2}$. Its thickness could exceed one $\mathrm{cm}$ at a distance of $10-15 \mathrm{~km}$ from the eruptive center. The volume of the material would likely be within $0.1-$ $1.0 \mathrm{~km}^{3}$.

It is hard to infer with confidence which of the versions will actually take place, particularly as the volcano itself and the seismicity in the Shchapinsky graben are not yet fully studied. We need to complete detailed studies on its eruptive activity during the last millennium, to analyze more carefully the evolution of the erupted products, and to study the state of the roots of the volcano by geophysical methods.

\section{Acknowledgement}

This paper was reviewed by C.P. Thornton and B. Voight. This contribution was intended for the special issue dedicated to Harry Glicken, but due to technical publication matters removed from the special issue.

\section{References}

Bogatikov, O.A. (Editor), 1981. Classification and Nomenclature of Magmatic Rocks. Nedra, Moscow, 160 pp. (in Russian).

Bogoyavlenskaya, G.E. and Braitseva, O.A., 1990. Genetic classification and types of pyroclastic deposits from 1955-1956 Bezymianny eruption. Volcanol. Seismol., 10(3): 386-412.

Bogoyavlenskaya, G.E. and Kirsanov, I.T., 1981. Twenty five years of activity of Bezymianny volcano. Volcanol. Seismol., 2: 3-13 (in Russian).

Braitseva, O.A., Florenskii, I.V., Ponomareva, V.V. and Litasova, S.N., 1989. The history of the activity of Kikhpinych volcano in the Holocene. Volcanol. Seismol., 7(6): 845-877.

Braitseva, O.A., Melekestsev, I.V., Ponomareva, V.V., Kirianov, V.Yu., Litasova, S.N. and Sulerzhitsky, L.D., 1991. Tephra of the largest pre-historic eruptions of Kamchatkan volcanoes in Holocene. Quaternary Int., in press.

Fedorov, M.B., 1972. On heterogeneity of magma melts of the Aag and Arik volcanoes. Bull. Volcanol. Stantsii., 48: 48-50 (in Russian).

Fedotov, S.A., Bagdasarova, A.M., Bobkov, M.F. and Kuzin, I.P., 1966. Earthquakes in Kamchatka and Commander Islands from the data of the detailed seismological observations during the period November 1961-1963. In: N.A. Vvedenskaya and N.B. Kondorskaya (Editors), Earthquakes in the USSR in 1963. Nauka Moscow, 186 pp. (in Russian).

Gill, J., 1981. Orogenic Andesites and Plate Tectonics. Springer, Berlin, $390 \mathrm{pp}$.

Glicken, H., 1988. Restudy of the 1888 eruption of Bandai volcano, Japan. Kagoshima International Conference on Volcanoes, Abstr., Kagoshima, p. 64.

Jackson, E.D., 1973. Variations of the chemical composition of coexisting chromite and olivine in chromite zones of the Stillwater complex. In: V.I. Smirnov (Editor), Magmatic Ore Deposits. Nedra, Moscow, pp. 43-66 (in Russian).

Kadik, A.A., Lebedev, E.B. and Khitarov, N.I., 1971. Water in Magma Melts. Nauka, Moscow, 267 pp. (in Russian).

Kadik, A.A., Maksimov, A.P. and Ivanov, B.V., 1986. PhysicoChemical Conditions for Crystallization of Andesites. Nauka, Moskow, 158 pp. (in Russian).

Kilinc, C., Carmichael, I.S.F., Rivers, M. and Sack, R.O., 1983. The ferric-ferrous ratio of natural silicate liquids equilibrated in air. Contrib. Mineral. Petrol., 83: 13G-140.

Kirsanova, T.P., Vergasova, L.P., Yuirova, L.M. and Taran, Yu.A., 1983. Fumarolic activity of Sheveluch and Kizimen volcano in 1979-1980. Volcanol. Seismol., 3: 33-42 (in Russian).

Kudo, A.W. and Weill, D.F., 1970. An igneous plagioclase thermometer. Contrib. Mineral. Petrol., 25, 1: 52-65. 
Lipman, P.W. and Mullineaux, D.R. (Editors), 1981. The 1980 Eruption of Mount St. Helens, Washington, U.S. Geol. Surv., Prof. Pap. 1250, 844 pp.

Luchitsky, I.V. (Editor), 1975. Kamchatka, Kuriles and Commander Islands. Nauka, Moscow, 440 pp. (in Russian).

Melekestsev, I.V., 1980. Volcanism and Ore Formation. Nauka, Moscow, 212 pp. (in Russian).

Melekestsev, I.V. Braitseva, O.A. and Ponomareva, V.V., 1989. Prediction of volcanic hazards on the basis of the study of dynamics of volcanic activity, Kamchatka. In: J.H. Latter (Editor), Volcanic Hazards. Assessment and Monitoring. Springer-Verlag, Berlin, pp. 10-35.

Melekestsev, I.V., Braitseva, O.A. and Ponomareva, V.V., 1990. Holocene activity dynamics of Mutnovskii and Gorelyi volcanoes and the volcanic risk for adjacent areas (as indicated by tephrochronological studies). Volcanol. Seismol., 9(3): 337362.

Ogorodov, N.V., Volynets, O.N., Koloskov, A.V. and Popolitov, E.I., 1978. Oiky Greben. Bull. Volcanol. Stantsii., 54: 75-88 (in Russian).

Petrov, V.S., 1970. Recent solfataric activity of Kizimen volcano. Voprosy Geografii Kamchatki, Petrapavlovsk-Kamchatsky, 6: 124-129 (in Russian).
Piip, B.I., 1946. Kizimen volcano. Bull. Volcanol. Stantsii., 13: 2232 (in Russian).

Powell, R. and Powell, M., 1977. Geothermometry and oxygen barometry using coexisting iron-titanium oxides: a reappraisal. Mineral. Mag., 41: 257-263.

Roeder, P.L. and Emslie, R.F., 1970. Olivine-liquid equilibrium. Contrib. Mineral. Petrol., 29(4): 275-289.

Shanser, A.E., Geptner, A.R., Egorova, I.A., Lupikina, E.G., Pevzner, M.A. and Chelebaeva, L.I., 1969. Volcanologic strata of the Tumrok ridge, their paleomagnetic characteristics and age. Izv. AN SSSR, ser. geol., 9: 72-82 (in Russian).

Shantser, A.E., Kutyev, F.Sh. and Petrov, V.S., 1973. Kizimen volcano. Bull. Volcanol. Stantsii., 49: 24-29 (in Russian).

Stuiver, M. and Kra, R. (Editors), 1986. Calibration Issue: Radiocarbon. V. 28, 2B: 805-1030.

Vlodavets, V.N. and Piip, B.I., 1957. A catalogue of the active volcanoes in Kamchatka. Bull. Volcanol. Stantsii., 25: 5-95 (in Russian).

Voight, B., Glicken, H., Janda, R.J. and Douglas, P.M., 1981. Catastrophic rockslide avalanche of May 18. U.S. Geol. Surv. Prof. Pap., 1250: 347-377.

Volynets, O.N., 1979. Heterotaxial lavas and pumices. In: The Problems of Deep Magmatism. Nauka, Novosibirsk, pp. 181-196 (in Russian). 